\title{
Lithostratigraphy and depositional environments in the Upper Paleocene and Eocene of Denmark
}

\author{
CLAUS HEILMANN-CLAUSEN, OLE BJøRSLEV NIELSEN and FLEMMING GERSNER
}

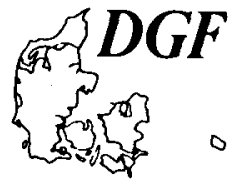

Heilmann-Clausen, C., Nielsen, O. B. and Gersner, F.: Lithostratigraphy and depositional environments in the Upper Paleocene and Eocene of Denmark. Bull. geol. Soc. Denmark, vol. 33, pp. 287-323, Copenhagen, February, 28th, 1985.

The Upper Paleocene and Eocene deposits of Denmark are described lithologically and are formally referred to six formations. The Upper Paleocene includes the Holmehus (new), Ølst (new) and the Fur Formations. The Eocene comprises the Røsnæs Clay, Lillebalt Clay and Søvind Marl Formations. The Ølst Formation is divided into Haslund and Værum Members. The Røsnæs Clay Formation and the Lillebælt Clay Formation are divided into twelve informal lithological units. The biostratigraphy (mainly calcareous nannoplankton and dinoflagellate zonations) of each formation is briefly outlined.

Previously unknown volcanic ash layers are recognized in the Holmehus, Røsnæs Clay and the Lillebælt Clay Formations, and a tephrachronology is established for the upper part of this ash sequence.

The petrography and geochemistry of the formations are described and regional and vertical variations in the parameters are related to changes in terrigeneous supply and depositional environment. Variations in the thickness of the formations are related to differential subsidence.

The depositional environment was marine to probably brackish and well below wave base. The sediments are mainly pelagic-like clays. Five major depositional phases are recognized, each represented by a formation (Ølst and Fur Formations being deposited during one phase). Phases of submarine non-deposition are identified at the base and top of the Ølst Formation. The Røsnæs Clay and Lillebælt Clay Formations include many widely distributed and regionally uniform, almost isochronous beds, each of a distinct lithology. They show that several widespread, rather sudden changes took place in a probably deep shelf environment with little regional variation. The changes are mainly ascribed to alterations in the marine circulation pattern.

C. Heilmann-Clausen, Palaoøkologisk Afdeling, Aarhus Universitet, DK-8000 Aarhus C, Denmark; $O$. B. Nielsen, Geologisk Institut, Aarhus Universitet, DK-8000 Aarhus C, Denmark; Flemming Gersner, Holme Møllevej 43, DK-8260 Viby J., Denmark, August 14th, 1984.

The purpose of this paper is to present a detailed survey of the Upper Paleocene and Eocene formations of Denmark. Together these formations constitute the Paleocene and Eocene plastic clays and ash-bearing clay and diatomite deposits at the Paleocene-Eocene boundary. Only one, the Fur Formation, has so far been precisely described (Pedersen \& Surlyk 1983) and will not be considered in detail here. The remaining five formations have previously been either imprecisely defined, or are first established here.

The earlier lack of precise knowledge of the stratigraphy may be explained by the poor quality of the exposures. The soft plastic clays have been badly disturbed by Quaternary glaciers, and furthermore they show a strong tendency to form slides which conceal cliff sections. The present study was facilitated by the availability of extensive exposures in the large clay pits at Ølst and Hinge in Eastern Jutland. This enabled us to es- tablish a key section through most of the Upper Paleocene and Eocene deposits, which in turn made possible precise correlation with coastal exposures around Denmark, and also with three cored boreholes which are described here.

Paramount to this study was the recognition of a number of lithologically distinct units, many of which are widely distributed and only show minor lateral variation. The boundaries are often sharp and synchronous, reflecting sudden, widespread changes within a probably deep shelf depositional environment.

The Upper Paleocene and Eocene stratigraphic record in Denmark is very similar to that of the North Sea. The Danish outcrops therefore provide an opportunity to examine visually these otherwise deeply buried sediments.

Future fieldwork, even on small and disturbed sections, will be greatly facilitated if the individual beds described below are identified. A pre- 
cise description of the lithology is therefore our main purpose.

\section{Previous work}

The previous work is briefly outlined, starting with the investigations of the oldest formation.

The first record of the Holmehus Formation (formally established in the present paper) is in Bøggild (1918), who mentions plastic clay occurring in borings beneath the ash-bearing strata now referred to the Ølst and Fur Formations. Andersen (1944) visualized on this basis that a general episode of fine-grained sedimentation took place in the south-eastern part of Denmark prior to the ash deposition. Dinesen (1965) and Dinesen, Michelsen \& Lieberkind (1977) described the Holmehus Formation in more detail from a borehole, LB 38, at the site of the New Lillebælt Bridge. Exposures of the Holmehus Formation at Vejle Fjord and on the island of Ebel $\emptyset$ were briefly described and correlated with the Thanetian Ceratiopsis speciosa dinoflagellate zone by Heilmann-Clausen (1980).

The Fur Formation of Pedersen \& Surlyk (1983) was described by Forchhammer in 1835 as being essentially a laminated diatomaceous deposit with many black sandy layers, geographically restricted to the western Limfjord area. Forchhammer applied the name Moeformation (now Fur Formation) after the local name moler (usually translated as mo-clay in English literature). The black sandy layers in the Fur Formation were recognized as volcanic ash beds by Prinz \& van Ermengem (1883). Bøggild (1903) identified the ash beds in a large area outside the Limfjord area in a silty clay deposit quite unlike the Fur Formation and formally defined as the $\emptyset$ lst Formation in the present paper. Similar ash beds were discovered in Northern Germany and originally described by Grönwall (1903), Elbert \& Klose (1904) and Gagel (1906). Ussing (1904, 1907, 1910) and Bøggild (1918) established a tephra chronology involving 179 ash layers in the Fur Formation. Bøggild (1918) described the lithology and mineralogy of the individual ash beds and also presented the first details of the outcrops of the $\emptyset$ lst Formation. The tephra chronology was extended to the Ølst Formation by Andersen (1937a). Isopach maps of several ash beds in general show increasing thicknesses towards the north (Andersen 1937a). This added weight to Bøggild's hypothesis that the volcano(es) was located north of the Limfjord area, probably in the Skagerrak. Norin (1940) studied the granulometry of the ash and his results indicate that the volcano was situated north or northwest of Jutland. Andersen (1938b) described the ash-bearing sequence from Northern Germany, distinguishing between a western type (Hamburg area), very similar to that of Denmark, and an eastern type from Greifswalder Oie (Northern DDR) where the ash beds are less distinct. Gry (1941) presented new lithological details on parts of the lower Fur Formation, especially the socalled Skiferserie, (shale sequence).

The boundary between the Ølst Formation and the underlying sediments, which had not at that time been observed in outcrops, is described from cored boreholes in the Viborg area by Flagler (1940) who interpretated the sharp contact as an unconformity.Pedersen (1981) in a study of several sections in the Limfjord area, describes an alternation between laminated and structureless diatomite throughout the Fur Formation, reflecting a bottom environment shifting between anoxic and low-oxygen conditions. The Fur Formation is formally established and the sedimentology, with special emphasis on the trace fossils, is described by Pedersen \& Surlyk (1983).

Various aspects of lithology, sedimentology and clay mineralogy of the Ølst and Fur Formations have been described by Gry (1935), Andersen (1958), Pedersen (1960), Tank (1963), Madirazza \& Fregerslev (1969), Petersen (1973), Nielsen (1973, 1974), Pedersen, Engell \& Rønsbo (1975), Pedersen \& Surlyk (1977) and Thiede, Nielsen \& Perch-Nielsen (1980). The results of a paleomagnetic study of the ash series are presented by Sharma (1969).

Paleontological and biostratigraphical information on the Fur and Ølst Formations are given by Prinz (1880, 1885), Prinz \& van Ermengem (1883), Ravn (1897), Stolley (1899), Gagel (1906), Hartz (1909), Henriksen (1922, 1929), Rosenkrantz (1945), Andersen (1947), Nielsen (1959, 1960, 1963), Koch (1960), Bonde (1966, 1982), Petersen (1969), Heie (1970), Benda (1972), Petersen, Hoch \& Bonde (1973), Hoch (1975), Larsson (1975, 1978), Perch-Nielsen (1976), Martini (1977), Hansen (1979), Pedersen 
(1981), Andersen (1982), Heilmann-Clausen (1982, 1983), Pedersen \& Surlyk (1983).

Paleoenvironmental studies of the Fur and $\varnothing$ lst Formations are given in Henriksen (1922), Andersen (1937b), Andersen (1947), Bonde (1966, 1973, 1974, 1979, 1982), Spjeldnæs (1975), Larsson (1975), Surlyk (1980), Pedersen (1981), Pedersen \& Surlyk (1983).

The first attempt to subdivide the plastic clay above the ash series was by Bøggild (1918: 113115), who mentions red calcareous clay occurring immediately above the ash series followed by non-calcareous, mainly grey clay overlain by calcareous clay. This three-fold division agrees roughly with the present division into the Røsnæs Clay Formation, Lillebælt Clay Formation and Søvind Marl Formation. The name Røsnæs Clay was suggested in 1906 by Ravn, who stated the age to be Early Eocene, based on the discovery of a specimen of the crab Glyphithyreus wetherelli, known from the London Clay and other contemporaneous deposits. Ravn (1928) added that the crab was found in the lower, mainly red part of the plastic clay. Harder (1922) suggested the name Lillebælt Clay for the complete plastic clay sequence above the ash series, despite Ravn's earlier proposal.Ødum (1936) restricted the name Røsnæs Clay to the lower, mainly red plastic clay, whereas the overlying mainly greygreen plastic clay was called the Lillebælt Clay. Ødum (1936) further suggested the age of the Lillebalt Clay to be Early Oligocene, based on the occurrence of the brachiopod Terebratulina nysti, (this species is now considered to be Eocene). Andersen (1938a) described the upper calcareous part of the plastic clay from marl pits in the Søvind area, and introduced the name Søvind Marl for this part. He specifically included the $T$. nysti-bearing localities in the Lillebælt area mentioned by $\emptyset$ dum (1936). Thereby he restricted the Lillebælt Clay to the non-calcareous, middle part of the Eocene plastic clay. Dinesen et al. (1977) introduced the term "Transition Strata" at the Røsnæs Clay/Lillebælt Clay and Lillebælt Clay/Søvind Marl boundaries. The positions of the units were indicated in some boreholes (Viborg 1 and LB 38). They also presented isopach maps of the Paleocene and Eocene, based on a large number of boreholes.

The occurrence of Eocene plastic clay is described or mentioned from borings and outcrops in several papers, the most important of which are: Bøggild (1918), Madsen, Ødum \& Gry (1935), Andersen (1937a), Flagler (1940), Milthers (1943), Sorgenfrei \& Berthelsen (1954), Dinesen $(1965,1972)$, Sorgenfrei \& Buch (1964), Petersen (1969, 1973), Berthelsen (1975), Rasmussen (1977), Dinesen et al. (1977), Gry (1979), Thiede et al. (1980).

Aspects of clay mineralogy and sedimentology of the Eocene plastic clay have been described by Mertz (1928, 1937), Clausen (1932), Unmack (1944, 1949), Graff-Petersen (1955), Tank (1963), Nielsen (1973, 1974), Gersner (1980), and Thiede et al. (1980). Tank (1963) subdivided the plastic clay into four successive clay mineral subzones, the uppermost one ranging into the Oligocene sediments. Thiede et al. (1980) subdivided the plastic clay into four successive lithozones, the uppermost of which ranges into the Oligocene Viborg Formation.

Information on the paleontology and biostratigraphy of the Eocene plastic clay is given by: Ravn (1897, 1906, 1915, 1928), Gagel (1917), Ødum (1936), Eriksen (1937), Flagler (1940), Berggren (1960a, b), Buch (1961), Rosenkrantz (1968), Perch-Nielsen (1967, 1968, 1971), Bonde (1968), Petersen (1969), Dinesen (1972), Rasmussen (1972), Caro (1973), Petersen et al. (1973), Hoch (1975), Heilmann-Clausen (1978, 1982, 1983), Hansen (1979), Thiede et al. (1980). The paleoenvironment is treated by Bonde (1968) and Spjeldnæs (1975).

\section{Lithostratigraphy}

\section{Holmehus Formation}

New formation

The name is derived from a farmhouse at the type locality on the Røjle peninsula (figs 1,2).

Previous names of the formation:

Bøggild (1918: 77) mentioned an outcrop of plastic clay at Holmehus which was assumed to be older than the previously known similar plastic clays of Eocene age. Dinesen et al. (1977) introduced the name Holmehus Clay and suggested that it probably represents a separate formation. Heilmann-Clausen (1980) used the term "Paleocene plastic clay" for this deposit. 


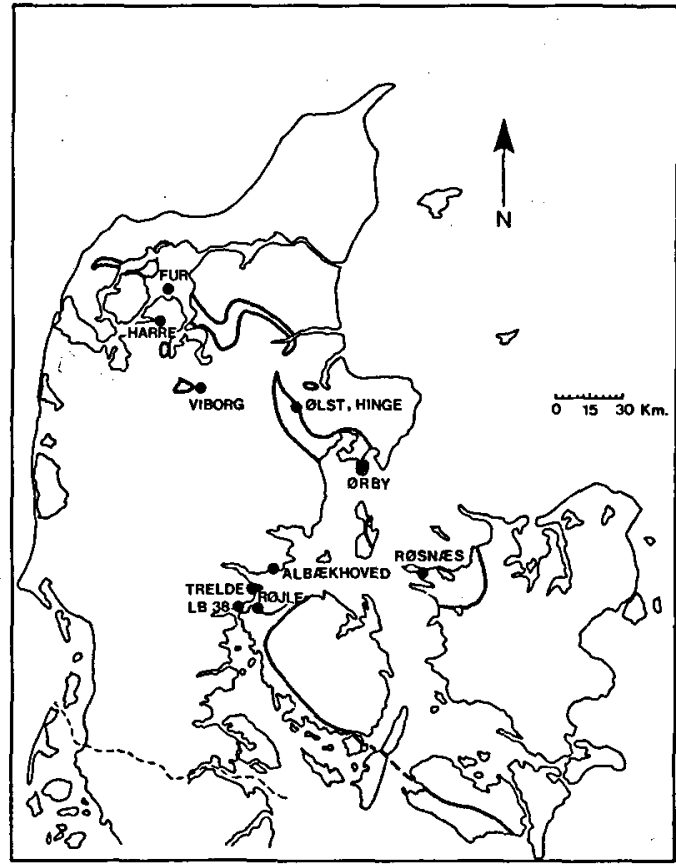

Fig. 1. Prequaternary map showing the distribution of the uppermost Paleocene and Eocene sediments (stippled) with the most important localities. To the north and east of the stippled area the uppermost Paleocene and younger sediments are absent, probably due to Quaternary erosion. To the south and west the Eocene and older sediments are covered by younger Tertiary deposits.

\section{Lithology:}

Non-calcareous, greenish, brownish and dark reddish, very fine-grained clay. Bedding is indistinct and burrows, including Zoophycos and Chondrites, are present. Scattered lenticular sideritic or phosphatic concretions, $10-20 \mathrm{~cm}$ large, occur. The clay is almost exclusively composed of smectite, and the very minor sand fraction consists mainly of diagenetic products, agglutinated foraminifera and sponge spicules. A bioturbated, volcanic ash layer is present at $\mathrm{Ny}$ Klitgård, NW Mors.

The detailed lithology of individual beds is unknown due to the poor quality of exposures and the few cored boreholes available for study.

\section{Thickness:}

The maximum known thickness is approximately $12 \mathrm{~m}$ in the LB 38 borehole at northern Lillebælt and in the Viborg 1 borehole in central Jutland. At $\varnothing$ lst the thickness is probably only a few meters.

\section{Lower boundary:}

The lower boundary is gradual. The Holmehus Formation is underlain by silty, slightly or noncalcareous clay deposits with silicified beds. These deposits have not been formally named. The transition is clearly marked by a color shift from the neutral grey of the silty deposits below to the greenish and brownish colour of the Holmehus Formation above, as well as by a decrease in grain size.

\section{Upper boundary:}

See description of the lower boundary of the $\emptyset$ lst Formation.

Distribution:

The Holmehus Formation is widely distributed in the Upper Paleocene of Denmark, as is evident from borehole material specified in Gry (1935) and Dinesen et al. (1977). In the North Sea, similar deposits seem to occur in the approximately contemporaneous Cen-1 Unit (Kristoffersen \& Bang 1982) and in the Lista Formation (Deegan \& Scull 1977).

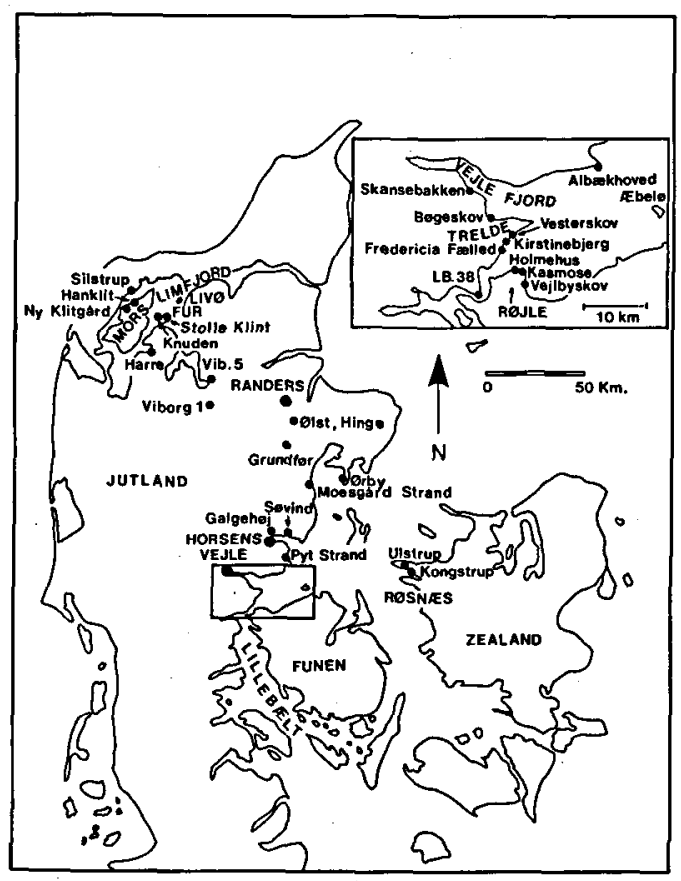

Fig. 2. Key-map of localities discussed in the text. Insertion: The northern Lillebxlt area. Exact map sheet references are given in table 2. 
Table 1. Thickness in meters of formations $(\Sigma)$ and members/beds at outcrops and boreholes. Italics indicate depths in meters below the surface. Where the precise depth of a lithological boundary is unknown, an interval is given. Where the boundaries of a unit are not observed, the measured thickness is indicated after the sign $>$. The geographical position of all localities is shown in table 2 . Abbreviations: $\emptyset$.Fm. $=$ Ølst Formation, F.Fm. = Fur Formation.

\begin{tabular}{|c|c|c|c|c|c|c|c|c|c|c|c|c|c|c|c|c|c|c|}
\hline \multicolumn{2}{|c|}{$\begin{array}{l}\text { Localities/ } \\
\text { Formations and } \\
\text { Mermbers }\end{array}$} & 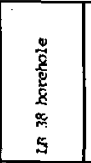 & 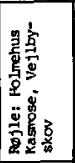 & 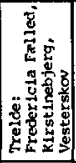 & 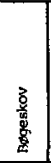 & $\begin{array}{l}\frac{\pi}{8} \\
\frac{5}{3} \\
\frac{5}{2}\end{array}$ & 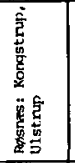 & 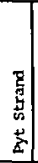 & 胥 & 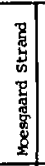 & $\frac{\frac{1}{5}}{5}$ & 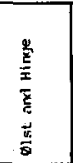 & 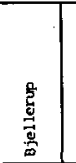 & 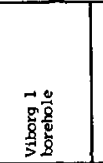 & 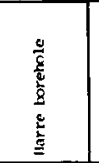 & 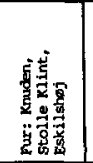 & 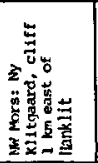 & 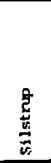 \\
\hline \multicolumn{2}{|c|}{ Sosind marl Porm. } & $\begin{array}{c}17.7 \\
4.0-7.3\end{array}$ & & & $>4.5$ & & & $>8$ & $>13$ & $>8$ & $>1.5$ & 4.3 & & $\begin{array}{l}254.3 \\
5 c .4\end{array}$ & 0 & 0 & & 0 \\
\hline \multirow{7}{*}{ 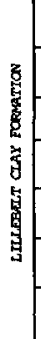 } & $\sum_{\text {Clay Form. }}^{\text {Lillebalt }}$ & \begin{tabular}{|l|}
$21.7-25$ \\
$64.3-69.5$ \\
\end{tabular} & $>11.6$ & $>30.2$ & & & $>11.15$ & & & & $>14.4$ & 37.6 & & $\begin{array}{l}304.7 \\
46.6\end{array}$ & $8.7-9.0$ & o? & & 0 \\
\hline & L 6 & 23.1-26.3 & & $>2$ & & - & & & & & & 8.8 & & 12.5 & $0^{\circ}$ & 0 & & 0 \\
\hline & 25 & {$\left[\begin{array}{l}18 \\
17.0\end{array}\right.$} & & $>9$ ar 6 & & & & & & & & 16 & & {$\left[\begin{array}{l}317.2 \\
>12.3 \\
-329.5\end{array}\right.$} & $\begin{array}{l}0 \\
177.0-\end{array}$ & 0 & & 0 \\
\hline & L 4 & 12.0 & $>6$ & $>10.6$ & & $>8$ & $>6$ & & & & $>10$ & 8 & & $\begin{array}{l}329.5 \\
<12.1\end{array}$ & $0.2-\mathrm{c} .5$ & 0 & & 0 \\
\hline & $\mathbf{L} 3$ & {$\left[\begin{array}{l}37 \\
1.3\end{array}\right]$} & 1.6 & $2.25-2.9$ & & 0.7 & 2.2 & & & & 0 & 1.2 & & {$\left[\begin{array}{c}341.8 \\
2.4\end{array}\right.$} & $\begin{array}{c}277.5 \\
1\end{array}$ & 0 & & 0 \\
\hline & L 2 & {$\left[\begin{array}{r}78.7 \\
6.3-9.6\end{array}\right]$} & $\sim 6$ & $>4.7$ & & 3.5 & $>2$ & & & & 3.6 & 2.7 & & $\begin{array}{c}344 \\
6 .\end{array}$ & $\begin{array}{c}178.5 \\
7.5\end{array}$ & 0 & & 0 \\
\hline & L 1 & $\begin{array}{c}-85-88.3 \\
1-6.2\end{array}$ & $\sim 2$ & & & 3.05 & 0.95 & & & & 0.6 & 0.9 & & $\begin{array}{l}350 \\
2.3\end{array}$ & $\begin{array}{l}-386 \\
0 ?\end{array}$ & $0 ?$ & & 0 \\
\hline \multirow{8}{*}{ 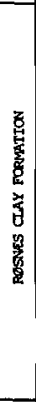 } & $\sum_{\text {Formation }}^{\text {Rosnes Clay }}$ & \begin{tabular}{|}
$89.3-91.2$ \\
$15.1-17.0$ \\
\end{tabular} & $>6.75$ & & & $>18.2$ & $>2.35$ & & & & 4.97 & 3.25 & & 7.8 & 4.85 & $6.05-7.55$ & & 0 \\
\hline & R 6 & $2.8-6.7$ & $1.85 ?$ & & & 5.3 & 0.35 & & & & 1.1 & 0.4 & & $0 ?$ & 0 & 0.27 & & 0 \\
\hline & R 5 & $T^{98-98}-T^{-9}$ & $t>4$ & & & & & & & & 2.4 & 0.65 & & $\begin{array}{l}351.3- \\
3.7\end{array}$ & 0 & $1-2$ & & 0 \\
\hline & R4 & -111. & $>4$ & & & $>12.9$ & $\rightarrow 2$ & & & & 0.7 & 1.05 & & $\begin{array}{l}355.1 \\
1.1-3.8\end{array}$ & 3 & $0.5-1$ & & 0 \\
\hline & B 3 & $0 ?$ & 0 & & & & & & & & 0 & 0.3 & & $0.2-2.9$ & $\begin{array}{r}189.0 \\
1.35\end{array}$ & 0 & & 0 \\
\hline & R 2 & & 0.50 & & & & & & & & 0.5 & 0.5 & & \multirow{3}{*}{$\begin{array}{c}0-0.2 \\
359.2 \\
0\end{array}$} & \multirow{2}{*}{0.5} & 0 & & 0 \\
\hline & R 1 & & 0.40 & & & & & & & & 0.3 & 0.35 & & & & 0.152 & & 0 \\
\hline & $\begin{array}{c}\text { Knudshoved } \\
\text { Mentiber }\end{array}$ & $\begin{array}{c}106.3 \\
0\end{array}$ & 0 & & & & & & & & 0 & 0 & & & $\begin{array}{c}190.85 \\
0\end{array}$ & 4.2 & $>3$ & 0 \\
\hline \multirow{3}{*}{ 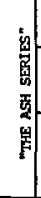 } & 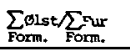 & $9.3 / 0$ & $>7.6 /$ & & & $>2.1$ & $>8.3 /$ & & & & $>16.9 /$ & $29.1 / 0$ & $>5.75 /$ & $22.2 / 0$ & $11.6 / 22.4$ & $>21 \quad \begin{array}{ll}50- \\
55\end{array}$ & $>3\rangle_{30}^{>25-}$ & $1>8$ \\
\hline & $\begin{array}{l}\text { "+ series " } \\
\text { Q.Fm.F.Fm. }\end{array}$ & & $7.0 / 0$ & & & $>2.1 \mid$ & $4.3 /$ & & & & $8.5 / 0$ & $9.1 / 0$ & & $8 / 0$ & $5.6 / 0$ & $0 /{ }_{25}^{20-}$ & $0 />15$ & $1>8$ \\
\hline & $\begin{array}{l}\text { - series " } \\
\text { ø.Fm./F,Fm. }\end{array}$ & 115.6 & $>0.68$ & & & & $>3.96 /$ & & & & $>8.4 /$ & $20 / 0$ & $|>5.75 f|$ & $\begin{array}{l}14.2 / 0 \\
381.3\end{array}$ & $\begin{array}{l}16 / 22.4 \\
\\
224.8\end{array}$ & $>2 / 30$ & $>3 /_{15}^{>10^{-}}$ & \\
\hline
\end{tabular}

Age:

Late Paleocene (Thanetian), Ceratiopsis speciosa dinoflagellate zone (Heilmann-Clausen 1980, 1983).

Type locality:

Holmehus, Røjle (fig. 2, tables 1, 2). The present authors have observed the Holmehus Formation by excavation beneath the classic exposure of the Ølst Formation from Holmehus. The contact between the two formations is probably influenced by glacial disturbances.

Previously the Paleocene age of the plastic clay beneath the Ølst Formation at this locality was not proven, and a correlation with borehole sections therefore uncertain (Bøggild 1918, Dinesen et al. 1977). However, a dinoflagellate analysis shows that it belongs in the Thanetian C. speciosa Zone, as in the reference sections.

\section{Reference sections:}

(For map-sheet coordinates, see table 2).

Boreholes: LB 38, from $115.6 \mathrm{~m}$ to about 128 $\mathrm{m}$ below surface. Detailed description in Dinesen (1965), Dinesen et al. (1977). Viborg 1, from 388 $\mathrm{m}$ to $400 \mathrm{~m}$ below surface, described by Flagler (1940).

Outcrops: The localities at Albækhoved and Ebelø (Heilmann-Clausen 1980). On Æbelø the green clay cropping out on the coast between the lighthouse and the abandoned boat harbour belongs to the Holmehus Formation. A section in 
Table 2. The geographical position, expressed as coordinates in the UTM grid, for outcrops and boreholes. Abbreviations: $H=H o l-$ mehus Formation, $\emptyset=\emptyset$ lst Formation, F = Fur Formation, $R=$ Røsnæs Clay Formation, $L=$ Lillebælt Clay Formation, $S=S ø v i n d$ Marl Formation, $\mathrm{Vi}=$ Viborg Formation, $\mathrm{Ve}=$ Vejle Fjord Formation.

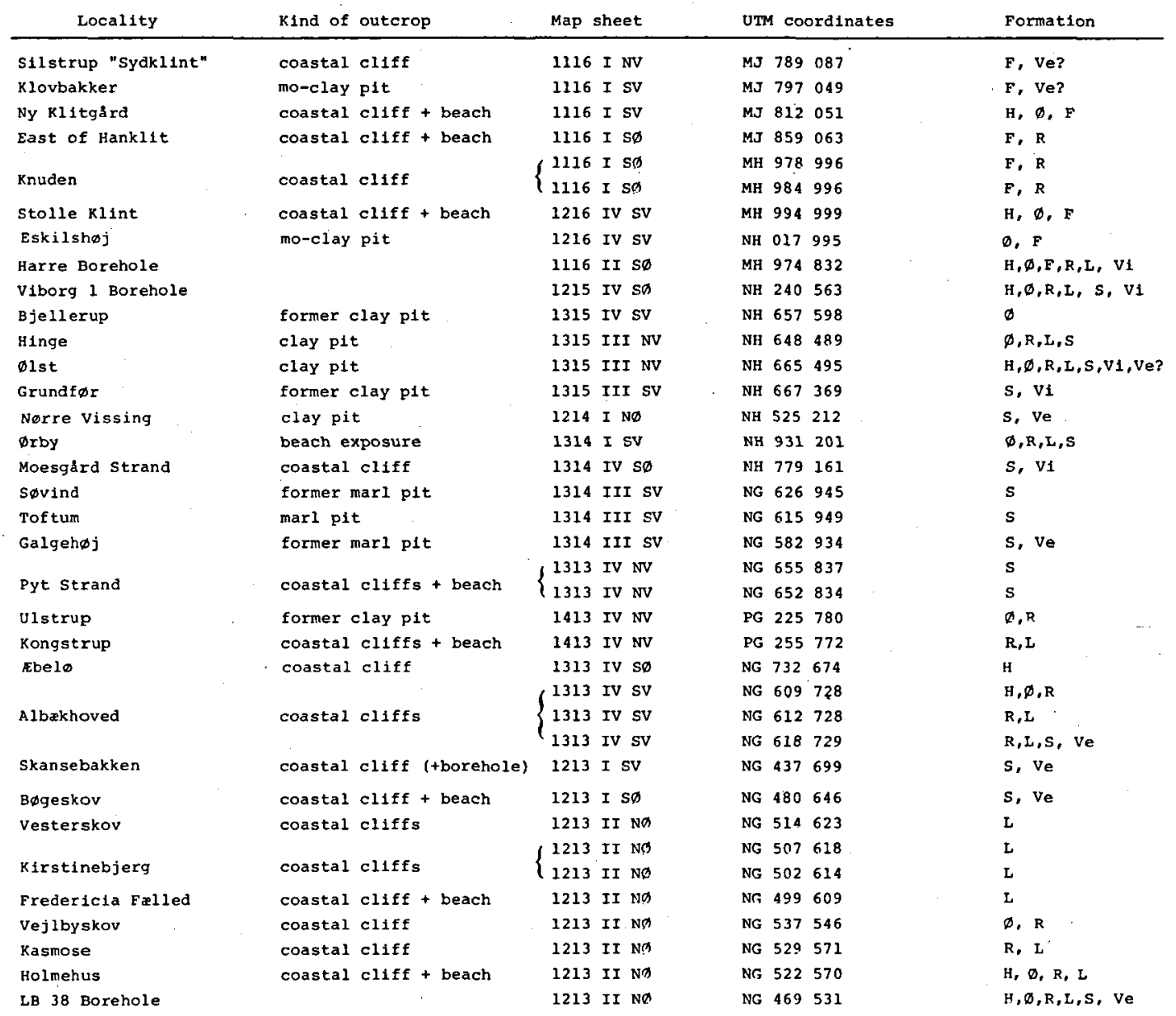

the clay pit at $\emptyset$ lst shows the boundaries. Very small outcrops may be observed on the beach in front of the sliding cliffs just west of Stolle Klint, Fur, and at Ny Klitgård, NW Mors. At the latter site the sedimentary contact to the $\emptyset$ lst Formation has been seen.

\section{$\emptyset$ lst Formation \\ New Formation}

The name is derived from the village of $\emptyset$ lst (figs 1, 2) about $10 \mathrm{~km}$ south of Randers, eastern Jutland.

Previous names of the Formation:

The sediments included in the $\emptyset$ lst Formation have previously been termed "Clay with Tuff" by Sorgenfrei (1957) and as "Clay with Volcanic Ash" by Dinesen et al. (1977). It is here proposed that the lowermost part of the Fur Formation (Pedersen \& Surlyk 1983) below ash layer 33, is included in the Ølst Formation.

\section{Lithology:}

A sequence of clays interbedded with beds and laminae of volcanic ash, partly argillized.

The clays are sandy, silty and non-calcareous. The colour is mainly dark grey. The clay is finely laminated in the lower part, while in the upper part both laminated and structureless intervals are present. Some layers include diatoms which are usually poorly preserved. Carbonate-ce- 
mented as well as partly silicified beds are present.

The volcanic ash beds are graded sandy and clayey silts of blackish or grey colour. The ash beds, numbered from +1 to +120 (Andersen 1937a), are closely spaced and their total thickness is approximately equal to the thickness of the clay in between, while the layers below are usually widely spaced and inconspicuous.

\section{Thickness:}

The thickness varies between $29 \mathrm{~m}$ at $\varnothing 1 s t$ and $9.3 \mathrm{~m}$ in the LB 38 borehole (table 1).

\section{Lower boundary:}

The $\emptyset$ lst Formation overlies the Holmehus Formation at most localities (figs $3,4,5$ ). Undisturbed exposures of the boundary are only accessible at Ølst and in a small beach section at $\mathrm{Ny}$ Klitgård, NW Mors. The boundary is sharp and marked by a glauconitic layer. At Viborg 1, a local unit of homogeneous silty clay with a sharp upper boundary is interbedded between the Holmehus Formation and the Ølst Formation (Flagler 1940).

Upper boundary:

In the western Limfjord area the Ølst Formation is overlain by the Fur Formation. The boundary between the two formations is close to ash layer -33 . Outside of this area the Ølst Formation is overlain by Bed R 1 of the Røsnæs Clay Formation, with which the boundary is sharp and marked by a hiatus. In eastern Jutland ( $\varnothing \mathrm{lst}$, Hinge, Ørby and Vejlbyskov) the top of the Ølst Formation may be synchronous, as the two ash beds +129 and +130 are found $0.2-0.5 \mathrm{~m}$ below the top (figs 6-10). On Røsnæs, according to Petersen (1973), the boundary with the Røsnæs Clay Formation is above ash bed +103 (fig. 11).

\section{Distribution:}

The Ølst Formation is known throughout the distribution area of the Danish Paleocene (fig. 1). In the western Limfjord area the Ølst Formation, except for the lowermost parts, is replaced by the Fur Formation (figs 3,5) and in the Harre borehole (fig. 1) the Ølst and Fur Formations interdigitate (figs 3,5 ).

Ash layers in contemporaneous sediments occur in the North Sea and in the surrounding land areas (Pannekoek 1956, Elliott 1971, Jacqué \& Thouvenin 1975, Knox \& Harland 1979, Knox \& Morton 1983, Malm et al. 1983). In the central and northern North Sea, Deegan and Scull (1977) established the "ash marker" as the Balder Formation, and the underlying laminated, tuffaceous shales as the Sele Formation. Dinoflagellate studies indicate that the Balder and Sele Formations together are probably equivalent to the $\emptyset$ lst Formation.

Age:

Late Paleocene?

The age is not firmly established. The Ølst Formation represents, together with the Fur Formation, the Apectodinium hyperacanthum dinoflagellate zone in Denmark (Heilmann-Clausen 1982). The zone is divided into a lower subzone (fig. 5) with abundant Apectodinium and an upper subzone dominated by Glaphyrocysta ordinata and Deflandrea oebisfeldensis. The boundary between the subzones occurs shortly above ash layer -33 in the Fur Formation, while in the $\emptyset$ lst Formation it corresponds to the top of the roughly $15 \mathrm{~m}$ thick laminated sequence in the lower part of the Haslund Member (fig. 5).

The A. hyperacanthum Zone is overlain by the Wetzeliella astra Zone which is present in the oldest part of the Røsnæs Clay (Heilmann-Clausen 1982). In northern Europe the boundary between the two zones has been equated with the Paleocene-Eocene boundary by Costa \& Müller (1978), based on a correlation between dinoflagellates and calcareous nannoplankton from the Rockall Plateau. Based on the dinoflagellates the Paleocene-Eocene boundary was thus indicated as lying between the Fur Formation and the Røsnæs Clay Formation (Heilmann-Clausen 1982).

However, Morton, Backman \& Harland (1983) present new evidence which casts doubt on the results of Costa \& Müller, and the exact position of the base of the $W$. astra Zone relative to the Paleocene-Eocene boundary is consequently still unknown. In the present study the Paleocene-Eocene boundary is provisionally placed at the base of the W. astra Zone.

\section{Type area:}

The clay pits at $\emptyset$ lst and Hinge (fig. 2, table 2) are chosen as the type area. 


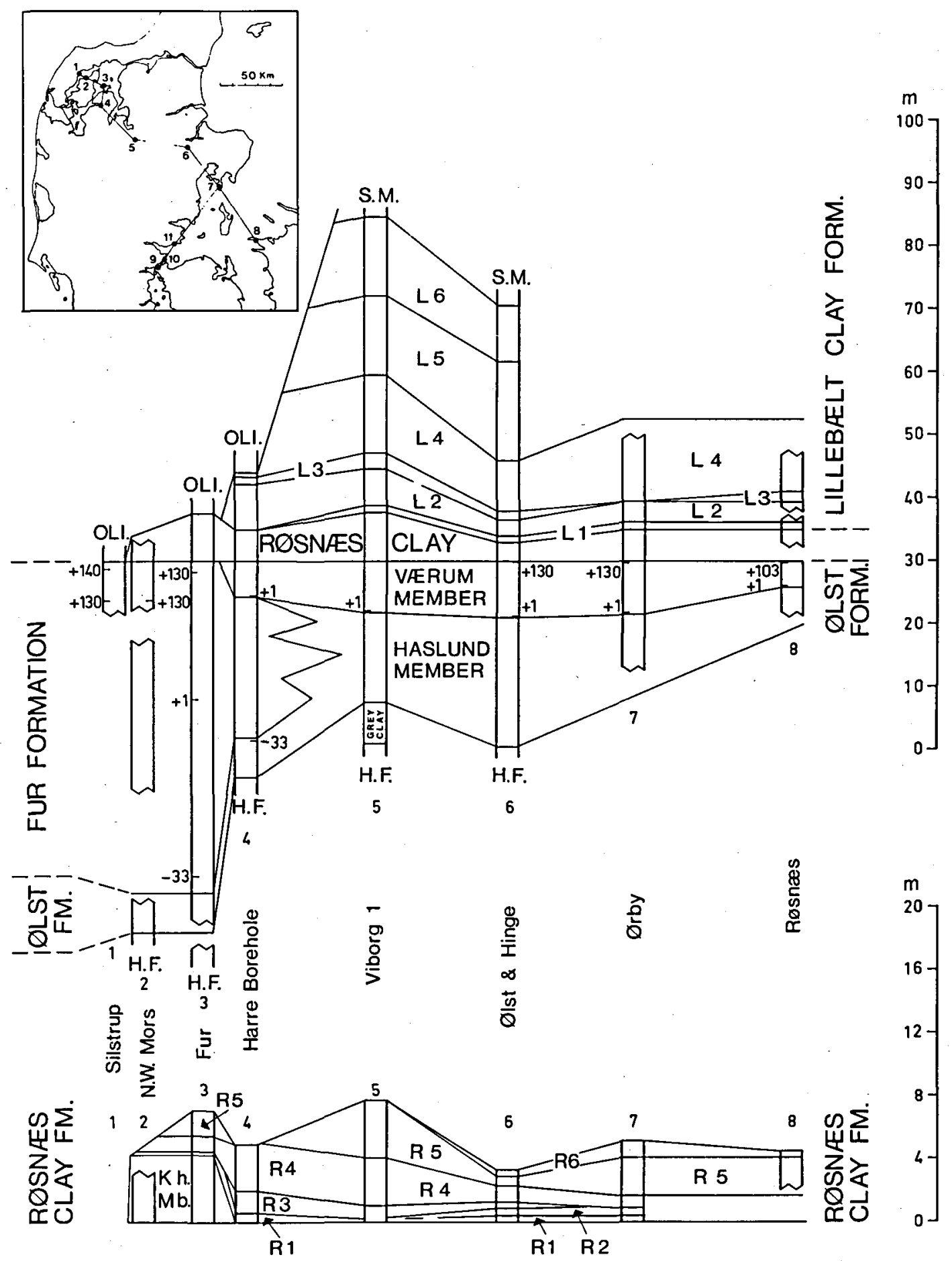

Fig. 3. Thickness variation in the Ølst, Røsnæs Clay and Lillebælt Clay Formations in a NW-SE section (above) and in a SW-NE section (opposite). Abbreviations: OLI. = Oligocene deposits, S.M. = Søvind Marl Formation, Kh.Mb. = Knudshoved Member, H.F. $=$ Holmehus Formation. Selected, numbered ash layers are indicated. 


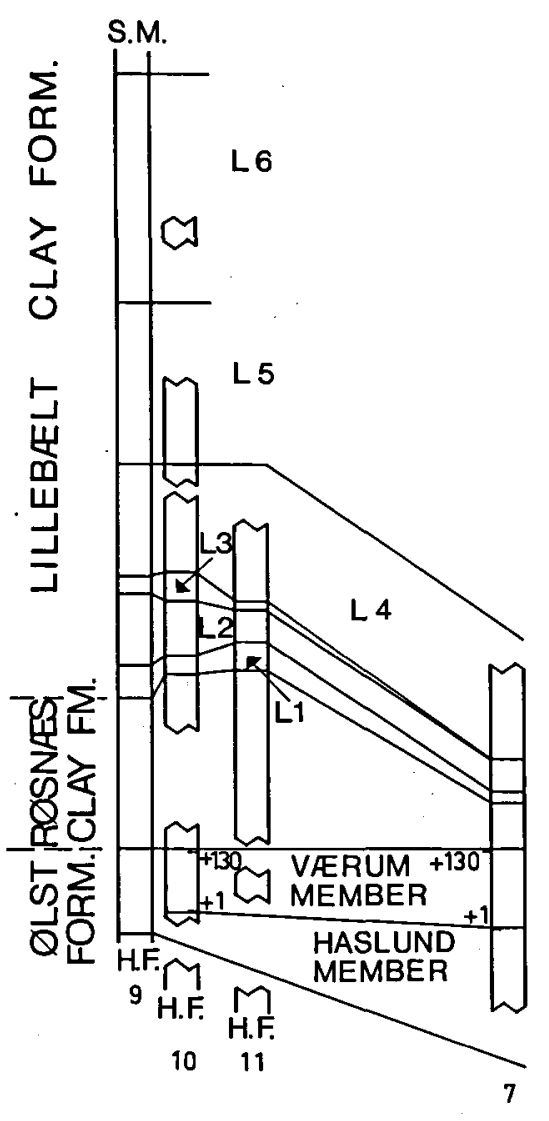

The uppermost $9 \mathrm{~m}$ of the formation at the $\varnothing$ lst pit were described by Nielsen $(1973,1974)$. At a road cutting close to the pit, Andersen (1937a) described the upper part of the Ølst For${ }_{100}^{m}$ mation and the lower part of the Røsnæs Clay, and correlated individual ash layers in the $\emptyset$ lst Formation with those in the Fur Formation.

Reference sections:

The sections at $\emptyset$ rby (fig. 9), Albækhoved, Holmehus (fig. 10), and Røsnæs (fig. 11) were described and measured by S. A. Andersen (1937a). L. J. Andersen (1958) studied sections in Randers, and Petersen (1973) described the formation from a now abandoned clay pit at Ulstrup, Røsnæs. Today only the sections at $\emptyset$ rby, Albækhoved, Røjle and perhaps Ulstrup are accessible. The $\emptyset$ rby cliff section of 1937 no longer exists. However, a beach section is exposed at low tide, showing an excellent vertical section of the Ølst Formation, including the entire Røsnæs Clay Formation and the lower part of the Lillebælt Clay Formation. Other sections of the Ølst Formation are shown in tables 1 and 2.

Subdivision of the $\varnothing$ lst Formation:

A lower Haslund and an upper Værum Member are here established. The names originate from villages in the vicinity of Ølst (fig. 2). Close to the villages, small exposures of the Ølst Formation have been described by Andersen (1937a).

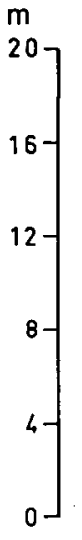

\section{Haslund Member}

Lithology:

The type section is shown in fig. 7 .

The Haslund Member consists of clays interbedded with a few volcanic ash layers.

The clays are greyish to olive-black, non-calcareous, silty and sandy. A lower, $15 \mathrm{~m}$ thick unit is distinguished by its notably fine lamination. In the upper $5 \mathrm{~m}$ the bedding structure is more variable, and partly silicified beds are common, especially around ash layers.

The ash beds vary in thickness between $7 \mathrm{~cm}$ and a few millimeters, most being less than one $\mathrm{cm}$. Ten layers are present below ash layer -13 at $\emptyset$ lst. It has not been possible to correlate these with layers in the numbered sequence of the Fur Formation. 


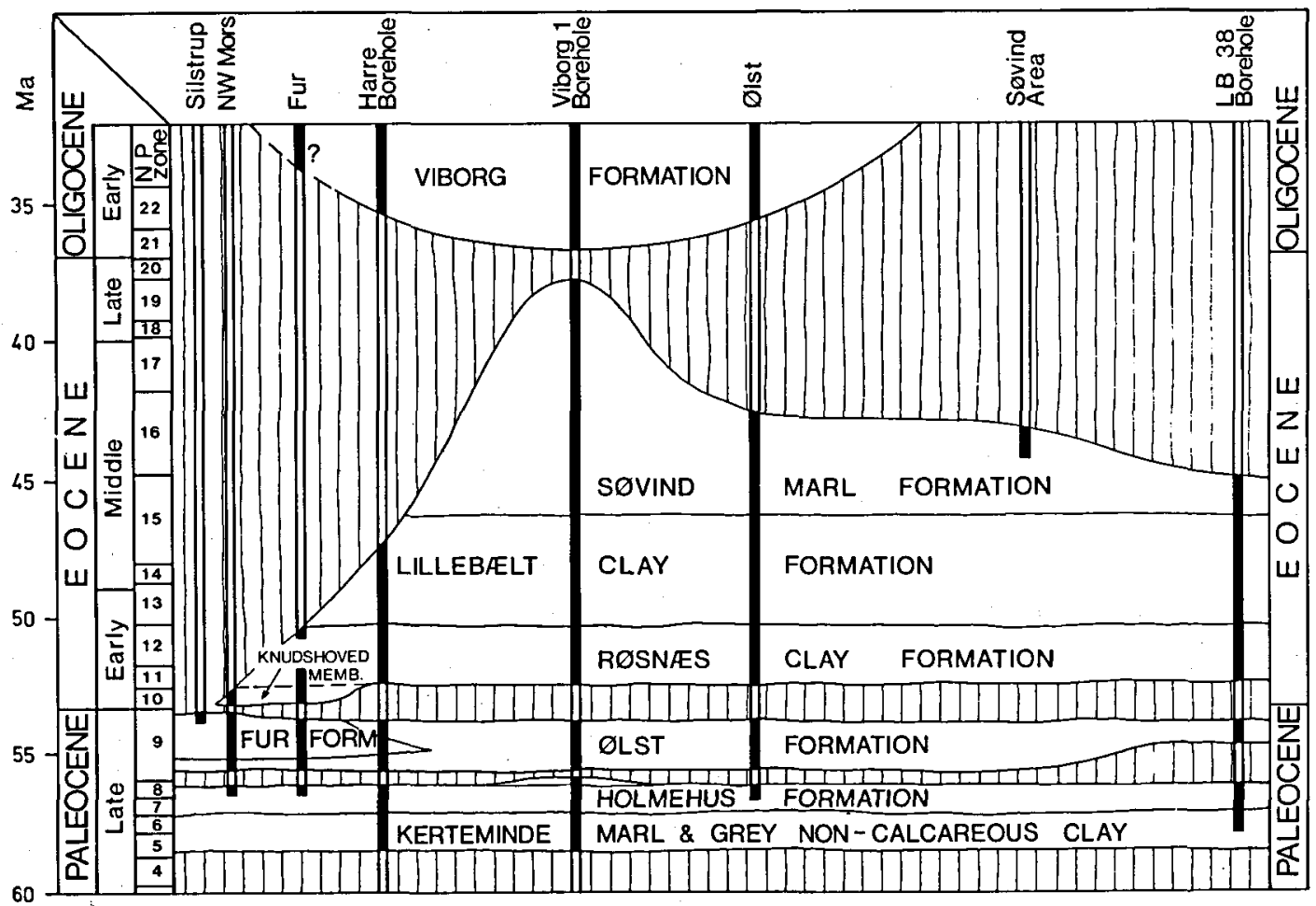

Fig. 4. Profile from the western Limfjord to the northern Lillebalt of the Late Paleocene to Early Oligocene deposits. The NP 6 NP 10 Zones and the NP 13 Zone are not identified, but have been inferred on the basis of dinoflagellate stratigraphy. The numerical time scale is from Hardenbol \& Berggren (1978).

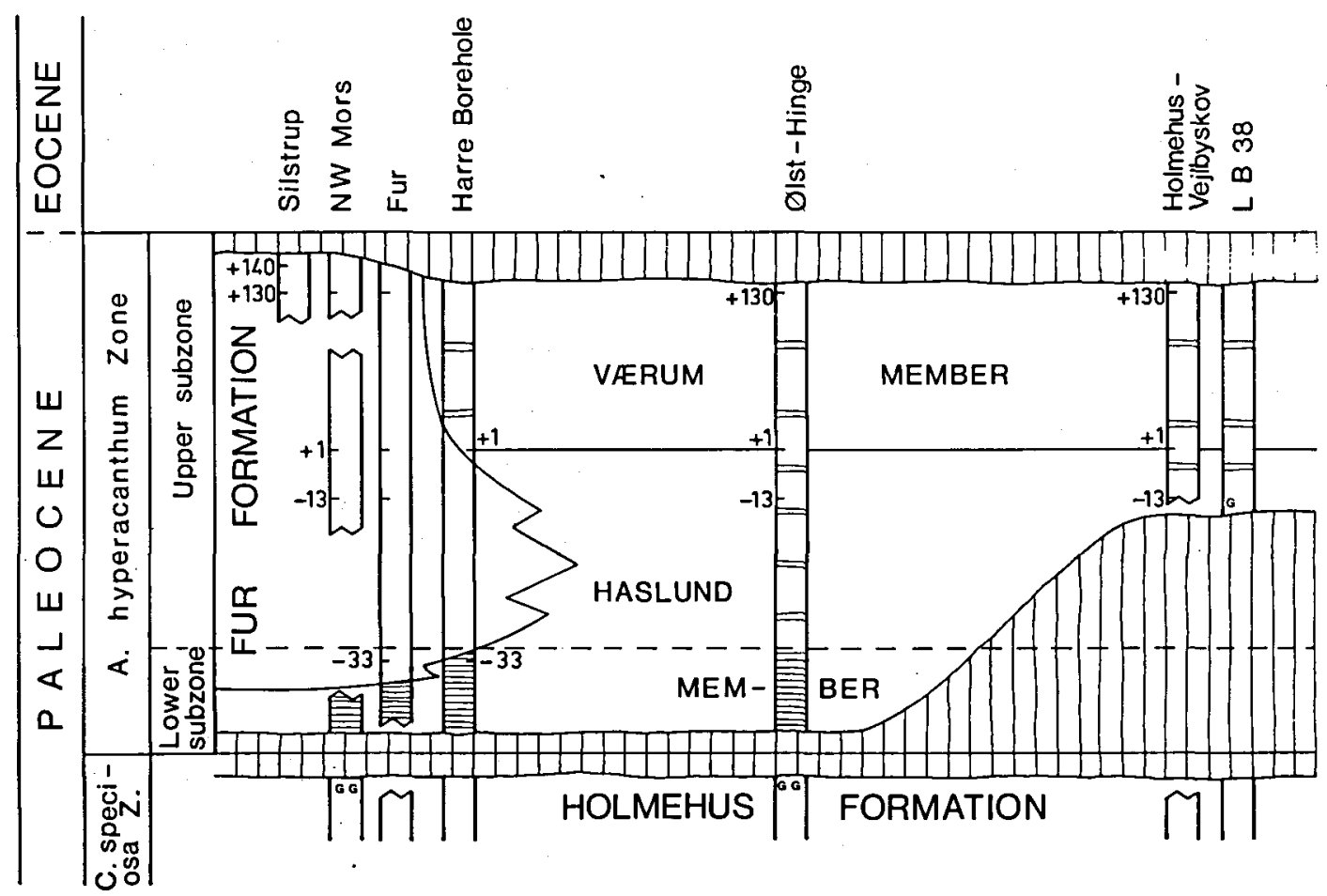

Fig. 5. Dinoflagellate stratigraphy and tephrachronology in the Fur and Ølst Formations. The subzones of the A. hyperacanthum Zone are described in the text. Lamination in the Ølst Formation is shown as horizontal lines. Abbreviation: $G=$ glauconite. 


\begin{tabular}{|c|c|}
\hline & Non-calcareous clay \\
\hline $\begin{array}{lll}1 & & 1 \\
1 & 1 & \\
\end{array}$ & $\begin{array}{l}\text { Calcareous clay, } \\
\text { or marl }\end{array}$ \\
\hline 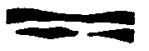 & Black, organic-rich clay \\
\hline$-V$ & $\begin{array}{l}\text { Volcanic ash layers } \\
\text { (argillized in the Røsnæs } \\
\text { and Lillebælt Clay). }\end{array}$ \\
\hline$-V 130$ & $\begin{array}{l}\text { Number according to } \\
\text { Andersen (1937a) }\end{array}$ \\
\hline$B$ & Concretion of barytes \\
\hline $\mathrm{Ph}$ & Phosphatic concretion \\
\hline G & Glauconite \\
\hline$\Phi$ & Carbonate concretion \\
\hline S & Partly silicified layers \\
\hline$\Leftrightarrow$ & Bioturbation \\
\hline
\end{tabular}

Fig. 6. Legend to figs $7-12$ and 14.

Thickness:

At the type locality the thickness is $20 \mathrm{~m}$.

Lower boundary:

The lower boundary is identical to the lower boundary of the $\emptyset$ lst Formation.

Upper boundary:

The upper boundary is placed just below ash layer +1 .

\section{Distribution:}

The stratigraphical relationships are outlined in fig. 5 .

In the Northern Lillebælt area only the uppermost part of the Haslund Member is present. Thus, at Holmehus the base is closely below ash layer -13 . As mentioned previously, the contact with the underlying Holmehus Formation is probably influenced by glacial disturbances at this locality. In the undisturbed section in the LB
38 borehole a similar section of the $\emptyset$ lst Formation is underlain by a one meter thick and highly glauconitic deposit (Dinesen 1965). The dinoflagellates in the sections at LB 38 and Holmehus show that the lower subzone within the $A$. hyperacanthum Zone is missing.

In the western Limfjord area only the lowermost part of the Haslund Member, belonging in the lower subzone of the $A$. hyperacanthum Zone, is present (fig. 5). It is finely laminated and very similar to the lower part of this member from $\varnothing$ lst. The Haslund Member is exposed immediately west of Stolle Klint and in the mo-clay pit at Eskilshøj, both on Fur, and in the cliff of Ny Klitgård, NW Mors. At the latter locality the sedimentary contact with the underlying Holmehus Formation may occasionally be seen in a small beach outcrop. On Fur and in the Harre borehole the boundary with the overlying Fur Formation has been observed close to ash layer -33 .

Formerly the outcrops of the Haslund Member at Stolle Klint and Ny Klitgård were correlated with non-calcareous clays occurring at Rugård and in several boreholes (Ussing 1913, Mertz 1928, Ravn 1928, Rasmussen 1967, Dinesen et al. 1977). The correlation is erroneous as it can be shown by the presence of an older, very different assemblage of dinoflagellates in the "Rugård Clay". The flora in the "Rugård Clay" includes in particular Palaeoperidinium pyrophor, Ceratiopsis striata and Palaeocystodinium australinum, and is without Apectodinium. A similar assemblage is present in a grey non-calcareous clay unit below the Holmehus Formation (in the boreholes Viborg 1, Harre and LB 38).

Type area:

The clay pits at $\emptyset$ lst and Hinge (fig. 2).

Reference sections:

The sections indicated in table 1 .

\section{Værum Member}

Lithology:

The type section is shown in fig. 7.

The Værum Member consists of clay interbedded with volcanic ash beds. The accumulated thickness of the ash beds amounts to almost half the total thickness of the member.

The clay beds are silty, sandy and non-calcare- 


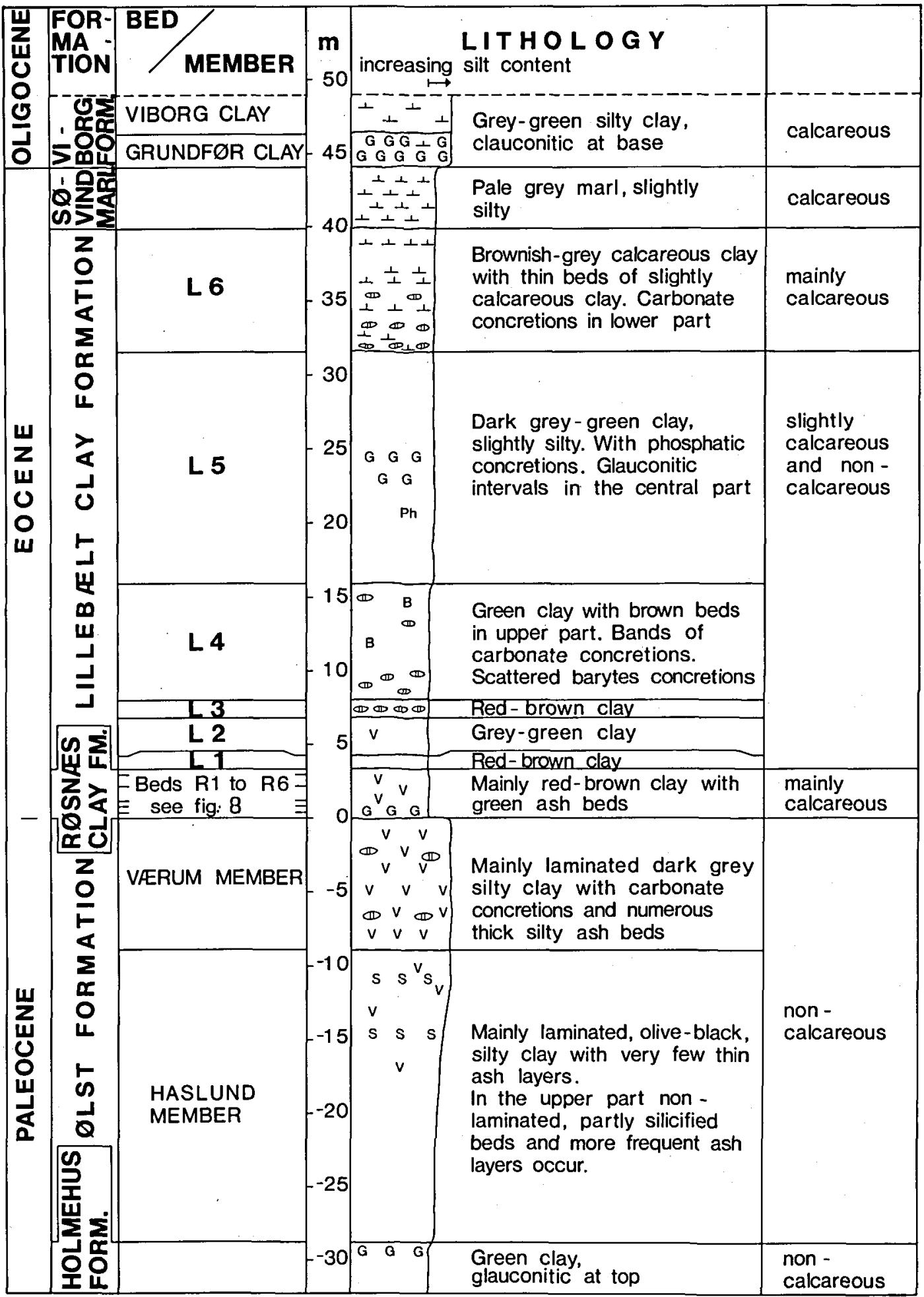

Fig. 7. Lithology and lithostratigraphy of Upper Paleocene to Lower Oligocene formations at Ølst and Hinge. Legend: see fig. 6. 
ous. Both laminated and bioturbated intervals are present. The colours are variable, dark grey, greenish grey and brownish grey. Some grey beds resemble the diatomite of the Fur Formation. In most cases, however, no well preserved diatoms are present. Carbonate cemented horizons mainly occur at three levels, especially around ash beds $+30,+77$, and +86 .

The sequence of ash beds in the Værum Member is the positive ash series of Bøggild (1918) and Andersen (1937a). The ash beds are up to 20 cm thick.

Thickness:

At the type locality the thickness is $9.1 \mathrm{~m}$.

Lower boundary:

The lower boundary is at the base of ash layer +1 .

Upper boundary:

The upper boundary is identical to the upper boundary of the $\varnothing 1$ st Formation.

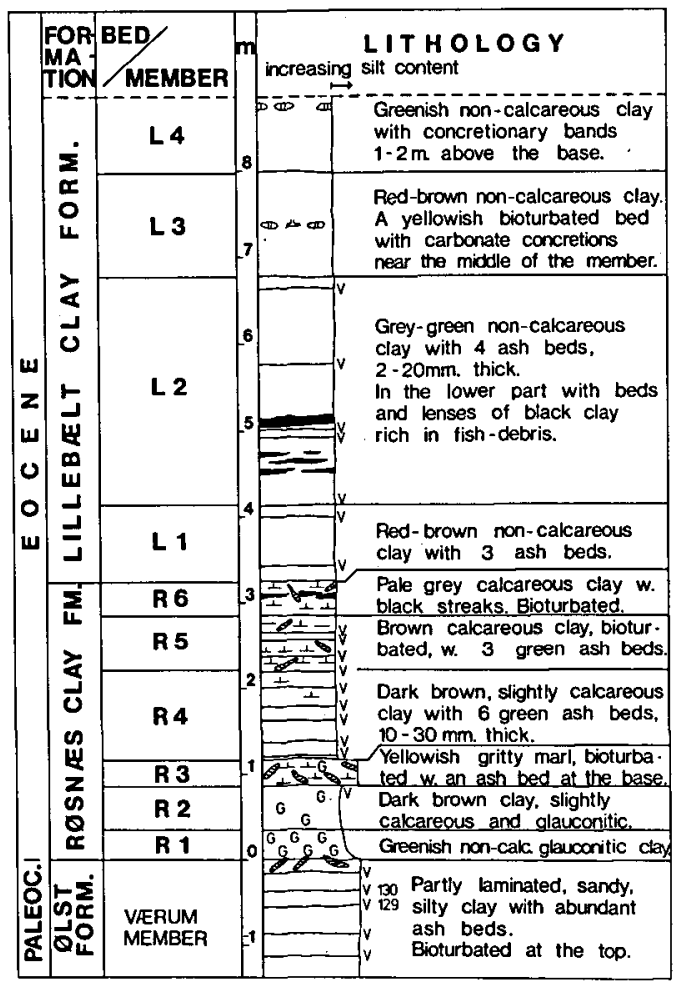

Fig. 8. Ølst and Hinge, detailed section of the Røsnas Clay Formation and parts of the over- and underlying formations. Legend: see fig. 6.

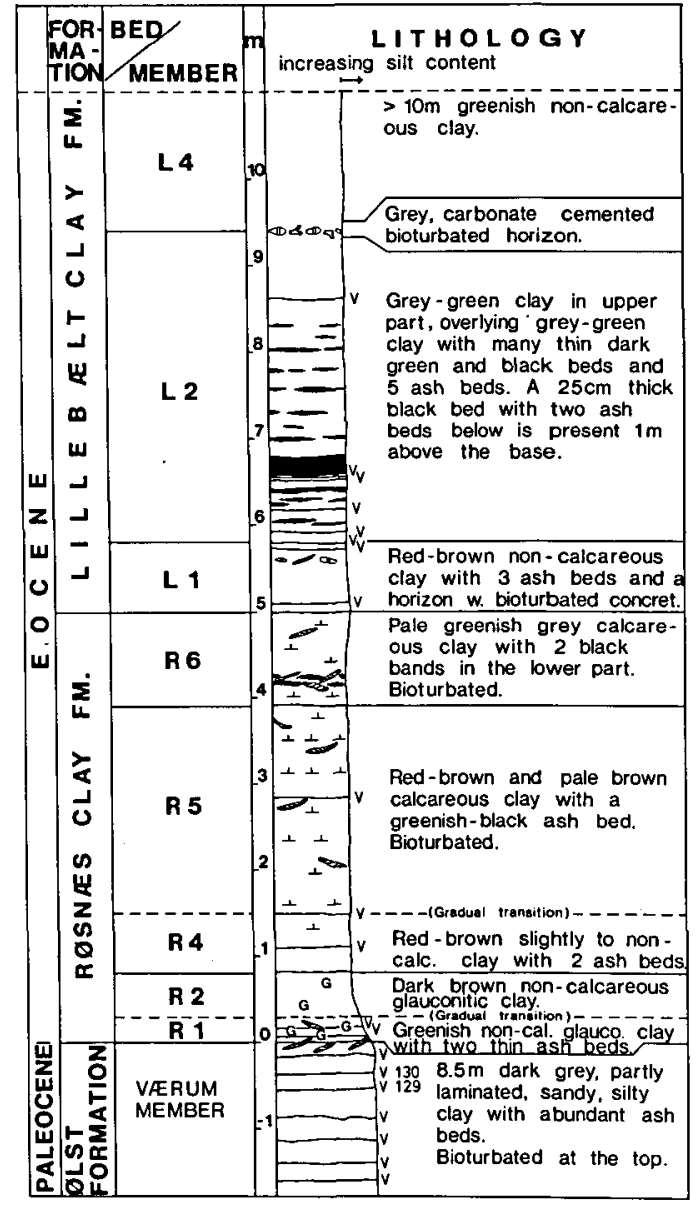

Fig. 9. Ørby, section of the Ølst, Røsnæs Clay and Lillebælt Clay Formations. Legend: see fig. 6.

\section{Distribution:}

The Værum Member is absent in the western Limfjord area where it is replaced by the equivalent part of the Fur Formation, i.e. the Silstrup Member.

Type area:

The clay pits at $\emptyset$ lst and Hinge (fig. 2).

\section{Reference sections:}

The sections indicated in table 1 .

\section{Fur Formation}

The Fur Formation is described in detail by Pedersen \& Surlyk (1983). Previously the formation, or parts of it, has been described by Bøggild 
(1918), Gry (1941, 1965, 1979), Rosenkrantz (1945), Pedersen (1981) and Håkansson \& Sjørring (1982).

A brief summary with special attention being given to the boundaries will therefore be sufficient here.

Essentially the Fur Formation is defined as a clayey diatomite with a large number of volcanic așh layers (Pedersen \& Surlyk 1983). It is distributed in the western Limfjord area and is a chronostratigraphical equivalent to the upper part of the Ølst Formation (figs 4, 5). The formation is subdivided into a lower Knudeklint Member and an upper Silstrup Member. The boundary between the two members is placed at ash layer +1 (Pedersen \& Surlyk 1983).

\section{Upper boundary:}

The Fur Formation is overlain by the Knudshoved Member of the Røsnæs Clay on Fur (Heilmann-Clausen 1982) and at the cliff $1 \mathrm{~km}$ east of Hanklint, NW Mors (Håkansson \& Sjørring 1982). In the Harre borehole (fig. 3) the Fur Formation is represented by diatomaceous layers together with the ash layers in the interval -33 to +1 . It is overlain by a very condensed, mainly non-diatomaceous section with the "positive series" of ash layers. This section is referred to the Værum Member of the $\emptyset$ lst Formation.

In Silstrup "Sydklint" (fig. 2) the Fur Formation is overlain by a thin Oligocene diatomite followed by micaceous clay (Heilmann-Clausen 1982).

\section{Lower boundary:}

A revision of the lower boundary is proposed here. It is suggested that the lower boundary should be placed near ash layer -33 . This differs from Pedersen \& Surlyk (1983) who place the boundary beneath ash layer -39 . We propose to include the non-diatomaceous deposits beneath ash layer -33 in the Haslund Member of the $\varnothing 1 s t$ Formation (figs 3, 5).

The boundary is accessible at Stolle Klint and in the mo-clay pit at Eskilshøj, Fur, where a tran-

Fig. 10. Røjle, composite section of Ølst, Røsnæs Clay and Lillebxlt Clay Formations. The lowermost section is measured at Holmehus (below ash layer 118) and Vejlbyskov (above ash layer 118). The middle section is measured at Kasmose, and the upper one is measured at Holmehus. Legend: see fig. 6 .

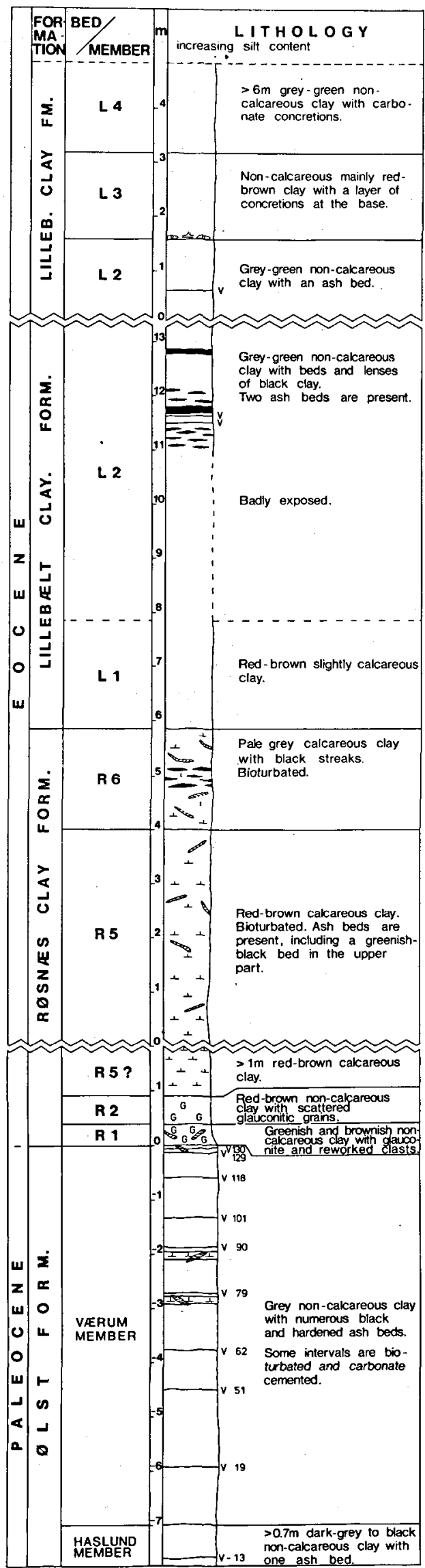


sition from the laminated clay (Haslund Member of $\varnothing$ lst Formation) to diatomaceous layers (Fur Formation) takes place just below -33. Eskilsh øj yields the most complete section and the sequence of ash layers present in the Haslund Member includes the interval from -39 to -34 . In the Harre borehole, which has a complete recovery, the lowermost diatomaceous layers occur just above ash layer $\mathbf{- 3 3}$.

\section{Røsnæs Clay Formation}

The name is derived from the Røsnæs peninsula in the western part of Zealand (figs 1,2).

Previous use of the name:

Ravn (1906) proposed the name Røsnæs Clay for deposits now separated into the Røsnæs Clay Formation, the Lillebælt Clay Formation and possibly also the Søvind Marl Formation. Ødum (1936) excluded sediments belonging to the Lillebælt Clay and Søvind Marl. The name has been applied in accordance with $\emptyset$ dum (1936) by Sorgenfrei (1957) and Dinesen et al. (1977), and is used in the same sense by the present authors.

\section{Lithology:}

Mainly redbrown and yellowish-brown calcareous and very fine-grained marine clay. Glauconitic beds of green and brown clay occur at the base. The uppermost bed is a spectacular light grey-green to almost white clay with a few laminae of black clay. Distinct greenish coloured, argillized volcanic ash layers, up to approximately 5 $\mathrm{cm}$ thick, are present throughout the formation. Trace fossils, mainly Zoophycos are common.

Thickness:

The Røsnæs Clay Formation varies between 3.25 $\mathrm{m}$ at $\emptyset \mathrm{lst}$ and at least $18 \mathrm{~m}$ at Albækhoved (table 1).

\section{Lower boundary:}

The Røsnæs Clay Formation overlies the Ølst Formation and the Fur Formation. Details are given below under description of the Knudshoved Member and bed R 1 .

\section{Upper boundary:}

The Røsnæs Clay Formation is overlain by the Lillebælt Clay Formation. The boundary is

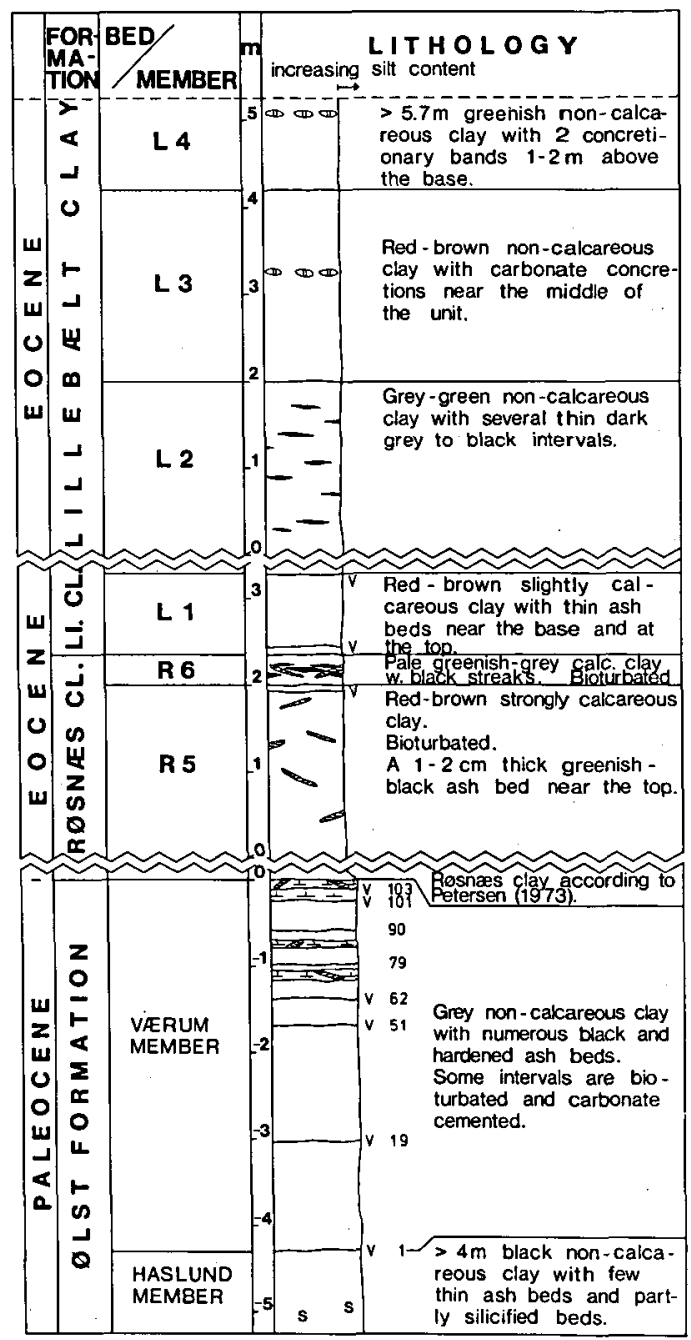

Fig. 11. Røsnæs, composite section of the Ølst, Røsnæs Clay and Lillebælt Clay Formations. The two uppermost sections are measured at Kongstrup and the lowermost one at Ulstrup. Legend: see fig. 6 .

placed at a sharp transition from the calcareous layers, usually bed R 6 of the upper Røsnæs Clay Formation, to the non-calcareous layers of the lower Lillebælt Clay Formation.

Distribution:

The Røsnæs Clay Formation is known throughout the distribution area of the Danish Eocene (fig. 1). A similar red fine-grained clay of approximately the same age is widely distributed in the North German "Untereozän 3" (Wirtz 1939, Bettenstaedt, Fahrion, Hiltermann \& Wick 1962, 
Hinsch 1974, Martini \& Müller 1971). According to Bettenstaedt et al. (1962: 343) the red clay is laterally replaced by a more sandy, glauconitic facies south and east of a line from Bremen through Hamburg to Fehmarn.

In extensive areas of the North Sea, red clay of the same age occurs directly above the ash series (Knox \& Harland 1979).

The Lower Eocene red clay in Northern Germany and in the North Sea clearly represents lateral extensions of the Røsnæs Clay Formation and consequently should be referred to this formation.

Age:

\section{Early Eocene.}

Thiede et al. (1980) assign the calcareous beds of the Røsnæs Clay Formation to the early Eocene NP zones 11 and 12. Other biostratigraphical investigations have also indicated an early Eocene age for the Røsnæs Clay: These are based on the occurrence of the crab Glyphithyreus wetherelli (Ravn 1906), foraminifera (Flagler 1940, Berggren 1960, Dinesen 1965, 1971, 1972, 1973 and Dinesen et al. 1977), dinoflagellates (Caro 1973, Hansen 1979 and Heilmann-Clausen 1982, 1983) and nannoplankton (Perch-Nielsen 1967, 1968, 1971 and Martini 1971, 1977).

\section{Type area:}

The Røsnæs peninsula (figs 1,2).

A type section has never been selected, and cannot be established at present. The sections visible today at Kongstrup and possibly at Ulstrup (fig. 11, table 2) are small and poorly exposed.

\section{Reference sections:}

Two sections with Røsnæs Clay overlying the Fur Formation were described by Heilmann-Clausen (1982) at Knuden on Fur. Other sections of the Røsnæs Clay are shown in figs 8-12 and tables 1, 2.

\section{Subdivision of the Røsnæs Clay Formation}

The Røsnæs Clay Formation includes seven distinct beds. The lowermost bed constitutes the

Fig. 12. Albakhoved, section of Røsnæs Clay and Lillebælt Clay Formations. Legend: see fig. 6.

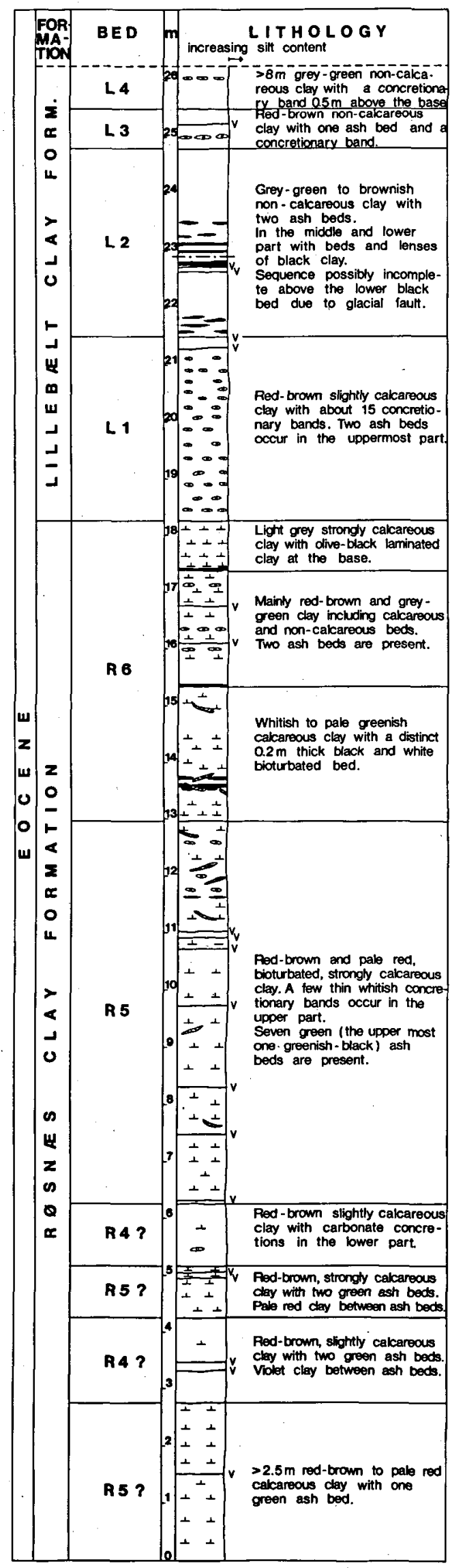


Knudshoved Member (Heilmann-Clausen 1982) which is restricted to the western Limfjord area. The remaining six beds are here named, from the base, $\mathrm{R} 1$ to $\mathrm{R} 6$. Despite some of the beds being thin, most of them are widely distributed and show only minor lateral variation.

In recent years the clay pits at $\emptyset$ lst and Hinge have yielded several complete sections of the Røsnæs Clay Formation. The exposures in this area serve as a key section of the Beds $R 1$ to $R 6$ (figs 9,13 ). The descriptions given below refer to this area.

\section{Knudshoved Member}

The section at Knuden, Fur, includes a basal silicified bed overlying the Fur Formation and followed by approximately $2 \mathrm{~m}$ of dark grey, pyritic, silty clay, and further by $2 \mathrm{~m}$ of greenish, finer grained clay.

Distribution: An almost identical sequence is found above the Fur Formation in the cliff $1 \mathrm{~km}$ east of Hanklit, NW Mors (figs 3, 4). This sequence is described by Håkansson \& Sjørring (1982).

The Knudshoved Member is limited to the western Limfjord area (figs 3,4 ).

Age: The Knudshoved Member belongs to the Early Eocene Wetzeliella astra dinoflagellate zone (the silicified bed only) and the W. meckelfeldensis Zone. The earliest specimens of Eatonicysta ursulae occur in the upper green part (Heilmann-Clausen 1982).

\section{R 1}

Greenish, glauconitic, bioturbated, non-calcareous clay. The lower boundary is sharp, marked by a shift from the dark grey, coarser-grained, non-glauconitic clays of the $\emptyset$ lst Formation to the clay of R 1. Burrows, mainly Zoophycos and Chondrites, filled with clay derived from $\mathrm{R} 1$ penetrate as far as $30 \mathrm{~cm}$ down into the $\emptyset$ lst Formation. The thickness at $\emptyset \mathrm{lst}$ is $35 \mathrm{~cm}$.

Distribution: At $\emptyset$ rby (fig. 9) the only noteworthy variation is a more gradational change in colour from greenish clay in Bed R 1 to brownish clay in Bed R 2. Two thin ash layers have been found at this locality.
At Vejlbyskov R 1 is $40 \mathrm{~cm}$ thick (fig. 10). It includes both greenish and reddish layers of highly glauconitic clay. Grey, reworked clasts are found in the lower part. The boundary to the underlying Ølst Formation is sharp.

At Knuden, Fur, a $15 \mathrm{~cm}$ thick layer of greenish, glauconitic clay, which possibly represents Bed $R$ 1, is found between the Knudshoved Member and Bed R 4 (fig. 3).

Age: At Hinge a dinoflagellate assemblage with early varieties of Eatonicysta ursulae is present in Bed R 1, which is therefore equivalent to, or younger than, the upper part of the Knudshoved Member. A hiatus corresponding to the $W$. astra Zone and the lower part of the W. meckelfeldensis Zone of earliest Eocene age is therefore present between the $\emptyset$ lst Formation and the Røsnæs Clay Formation at Hinge.

\section{R 2}

Dark brown, slightly calcareous clay with upwards decreasing amounts of glauconite. The thickness at $\varnothing$ lst is $50 \mathrm{~cm}$.

Distribution: At $\emptyset$ rby the thickness is $50 \mathrm{~cm}$, as at Ølst. Zoophycos burrows are frequent. The colour of the clay varies between light and dark reddish brown. Some glauconite grains almost reach one centimeter in diameter.

At Vejlbyskov no variation in lithology has been noted and the thickness is again $50 \mathrm{~cm}$. The boundary between Beds R 2 and R 5 is defined by the disappearance of glauconite.

In the LB 38 borehole a sample from the lowermost meter of the Røsnæs Clay Formation is typical for Bed R 2.

\section{R 3}

Yellowish brown intensely bioturbated marl. This unit has a characteristic gritty texture. It contains a large amount of sand-sized grains including mainly foraminifera and a small amount of glauconite.

The lower boundary is marked by a green $2-3$ $\mathrm{cm}$ thick argillized ash layer. The thickness of R 3 at $\emptyset \mathrm{lst}$ is $30 \mathrm{~cm}$.

Distribution: The contact between Beds R 2 and R 5 at $\varnothing$ rby and Vejlbyskov (figs 9,10 ) indicates 
w.

E.

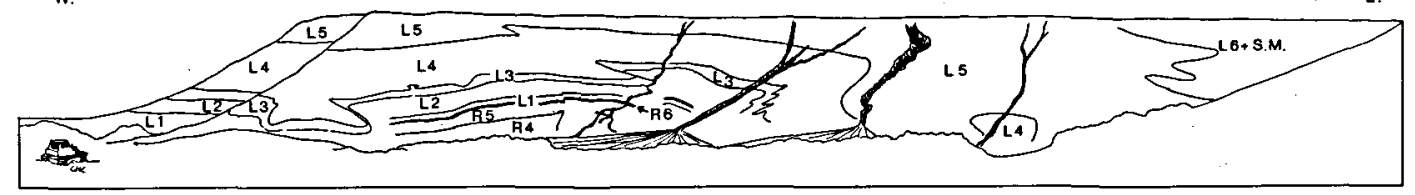

Fig. 13. The 25-30 m high slope in the north-eastern part of the clay pit at Hinge, exposing the Beds R 4 to $\mathrm{R} 6$ of the Røsnas Clay Formation, L 1 to L 6 of the Lillebalt Clay Formation and parts of the Søvind Marl Formation (S.M.). After a photograph, 1981.

that R 3 is most likely absent in the area to the south and southeast of $\emptyset$ lst. To the northwest, at Harre and Viborg 1, R 3 is present and in the Harre borehole the thickness is as much as 1.35 $\mathrm{m}$ and the lithology is typical. In the Viborg 1 borehole the only sample available in the lower $2.9 \mathrm{~m}$ of the Røsnæs Clay has the typical lithology of Bed R 3.

\section{R 4}

Dark reddish brown, slightly calcareous clay. The carbonate content increases upwards. Six green to dark green argillized ash layers up to 2-3 $\mathrm{cm}$ thick are present.

The lower boundary is sharp. The thickness at $\emptyset$ lst is $105 \mathrm{~cm}$.

Distribution: See Bed R 5.

\section{R 5}

Light reddish yellowish brown, highly calcareous clay. Zoophycos burrows are common. In the upper part of the bed three argillized ash layers occur; the lower two are greenish and the upper one is greenish black.

The lower boundary is defined where the carbonate content exceeds $20-25 \%$, coinciding with a marked shift to a light colour. The thickness at $\emptyset 1 \mathrm{st}$ is $65 \mathrm{~cm}$.

Distribution of Beds R 4 and R 5: The sections at $\emptyset$ rby (fig. 9) and in Viborg 1 (table 1) are similar to $\emptyset 1$ lst, i.e. they include a lower, less calcareous sequence (R 4) and an upper, more calcareous part (R 5).

At Harre (table 1), the whole section of red clay above Bed R 3 is non-calcareous and is therefore referred to Bed R 4. Further north, at Knuden, Fur (table 1) a lower non-calcareous
Bed R 4 and an upper calcareous Bed R 5 are present.

In the Vejle Fjord - Lillebælt area the Røsnæs Clay reaches a much greater thickness than to the north (table 1). It consists mainly of red, strongly calcareous clay similar to Bed R 5. This is best seen in the well exposed almost complete sections at Albækhoved (fig. 12), where slightly calcareous clay is only present in two thin intervals (indicated as R 4 ? in fig. 12). In the LB 38 borehole most of the red beds in the Røsnæs Clay Formation are also calcareous (Dinesen 1965).

Ash layers in R 4 and R 5: Twelve ash layers, most of them green, have been found at Albækhoved. Like at $\emptyset$ lst, the uppermost ash layer at Albækhoved, Ørby, and Kongstrup has an unusual greenish black colour and is therefore assumed to be the same layer. It has not yet been possible to correlate any of the other ash layers in R 4-R 5.

\section{R 6}

This consists of light greenish grey, calcareous clay, which is almost white when dry. In the middle of Bed R 6 is a layer of black clay, rich in organic matter and including fish debris. Frequent Zoophycos burrows penetrating both light grey and black clay are filled with a spectacular mixture of the two lithologies and gives this bed a very distinct mottled character. The lower and upper boundaries are sharp. The $\mathrm{R} 6 \mathrm{Bed}$ is overlain by the Lillebælt Clay Formation. The thickness at $\varnothing$ lst is $40 \mathrm{~cm}$.

Distribution: The thickness and lithology at Kongstrup (fig. 11) is very similar to Ølst. At $\emptyset$ rby the thickness is $1 \mathrm{~m}$ and the characteristic three-fold division of the bed is again observed (fig. 9).

Albækhoved (fig. 12) shows the maximum 
thickness of Bed R 6,5.3 m. The black layer occurs 0.7 to $0.9 \mathrm{~m}$ above the base, with the usual whitish clay below. It is overlain by a $4.5 \mathrm{~m}$ thick sequence consisting mainly of light grey clay and marl beds, but also including layers of brownish and green clay (for details, see fig. 12).

\section{Lillebælt Clay Formation}

The name is derived from Lillebælt, the strait between Jutland and Funen.

Previous and present use of the name:

Harder (1922) proposed the name Lillebælt Clay for deposits that today include the Røsnæs Clay Formation, the Lillebælt Clay Formation and the Søvind Marl Formation. Ødum (1936) excluded the Røsnæs Clay from the Lillebælt Clay, but included calcareous beds here referred to the Søvind Marl Formation.

Dinesen et al. (1977) established two transitional series, one between the Røsnæs Clay and the Lillebælt Clay, and one between the Lillebælt Clay and the Søvind Marl. The Lillebalt Clay Formation as proposed in the present paper includes the lower transitional series and part of the upper one.

Lithology:

Mainly grey-green, non-calcareous, extremely fine-grained clay. Beds of reddish-brown clay are present in the lower and middle parts of the formation. Slightly silty beds occur near the base and top. Paler calcareous beds are interbedded near the top.

The Lillebælt Clay includes various kinds of concretions; mixed-carbonate and phosphatic ones are common, while concretions of barytes and pyrite are less frequent.

\section{Thickness:}

The Lillebælt Clay Formation varies between nearly $70 \mathrm{~m}$ in the LB 38 borehole and only about $9 \mathrm{~m}$ in the Harre borehole (table 1).

Lower boundary:

The Lillebælt Clay Formation overlies the Røsnæs Clay Formation. See the description of the Røsnæs Clay Formation for details.

Upper boundary:

The Lillebælt Clay Formation is overlain by the
Søvind Marl Formation. The boundary is placed where the colour changes to light grey, above which the carbonate content is constantly high.

\section{Distribution}

The Lillebælt Clay Formation is present throughout the area with Eocene sediments in Denmark (fig. 1), except in northern Jutland. Along a section from Harre across Fur to Silstrup it seems that progressively larger parts of the Eocene are missing, due either to non-deposition or to preChattian erosion (fig. 4). However, on the island of Livø (fig. 2) north-east of Fur, samples of the Lillebælt Clay Formation and the Søvind Marl Formation have been identified in the badly exposed and small outcrops on the western coast. The distribution of Eocene deposits in the Limfjord area therefore seems to be rather irregular.

Contemporaneous deposits in northern Germany are described by Bettenstaedt (1944), Illies (1949), Bettenstaedt et al. (1962) and Hinsch (1974). The green, non-calcareous "Tarras" facies in "Untereozän 4" correlates with the lower Lillebælt Clay Formation. Due to the close similarity, we propose to include the green "Tarras" in the Lillebælt Clay Formation. Sandy silicified clays, the so-called Heiligenhafener Kieselgestein, are found in the upper part of "Untereozän 4" and a sandy facies is also present in the lower "Obereozän" in Holstein. The upper Lillebalt Clay Formation is gradually replaced to the south by these sandy sediments.

In the North Sea the Lillebælt Clay Formation seems to be widely distributed, but at present its precise extent is unknown.

Age:

Early? - Middle Eocene.

Thiede et al. (1980) assign the uppermost part of the Lillebælt Clay Formation from the Viborg 1 borehole to the Middle Eocene NP zones 14 and 15. No nannoplankton zonation is available for the lower and middle part of the Lillebalt Clay Formation which is essentially non-calcareous. Samples referred to the Lillebalt Clay by Perch-Nielsen (1971) belong to the Søvind Marl Formation as defined here.

Previous biostratigraphical work is based on foraminifera (Flagler 1940, Dinesen 1965, 1972, Dinesen et al. 1977) and dinoflagellates (Caro 1973, Heilmann-Clausen 1978, 1983). 
Type area:

The northern Lillebælt area.

A specific type section has never been established, and no single section in the Lillebælt area includes a complete sequence of the Lillebælt Clay Formation.

The lower and middle Lillebælt Clay Formation is well exposed in several up to $15 \mathrm{~m}$ high coastal cliffs at Trelde and Røjle (table 2). The upper part of the Lillebælt Clay is visible at several localities on the Lillebælt coast at Trelde, but only temporary, small sections can be found due to cliff instability.

Sections of the Lillebælt Clay from the type area are shown in figs 10 and 14.

\section{Reference sections:}

Figs 7-9, 11-12, tables 1, 2.

\section{Subdivision of the Lillebælt Clay Formation}

Six distinct lithological units are present in the Lillebælt Clay Formation, named from the base L 1 to $L$ 6. Despite the fact that some of the beds are relatively thin, they are widely distributed. They show only minor lateral variation, and their boundaries are approximately synchronous, as indicated from tephrachronology and biostratigraphy. The exposures in the clay pits at $\emptyset$ lst and Hinge serve as a key section (figs $7,8,13$ ) since the most complete and best studied sections are present here. The descriptions given below refer to these exposures.

\section{1}

Red-brown non-calcareous clay with a greenish volcanic ash layer, 1-2 cm thick, near the base. Two closely spaced ash layers are found at the upper boundary. The upper one is almost $2 \mathrm{~cm}$ thick, while the lower one is discontinuous and less than $0.5 \mathrm{~cm}$ thick. The thickness at $\emptyset \mathrm{lst}$ is 0.9 m.

Distribution: No significant variations in lithology or thickness occur at Ørby and Kongstrup,

Fig. 14. Trelde, composite section of Lillebalt Clay Formation. The lowermost section is measured at Fredericia Falled and Kirstinebjerg, the middle section at Vesterskov and the uppermost one at Kirstinebjerg. Legend: see fig. 6.

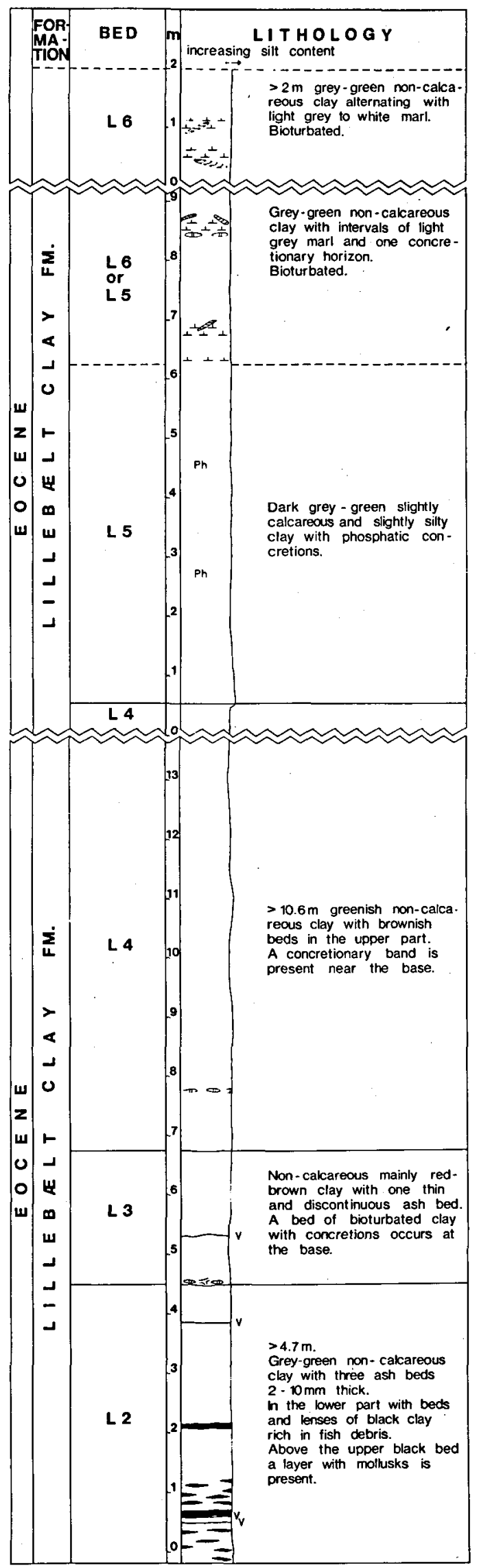


apart from a thin bioturbated concretionary layer at Ørby (fig. 9).

The thickness at Albakhoved (fig. 12) is as much as $3.05 \mathrm{~m}$ and approximately 15 thin and evenly spaced discontinuous concretionary layers are present. Two ash layers are found at the upper boundary at $\emptyset$ rby and Albækhoved (figs 9, 12 ), as at $\emptyset$ lst. At Kongstrup only one ash layer has been observed. The ash layers demonstrate that the boundary between Beds $L 1$ and $L 2$ is synchronous.

\section{2}

This is a grey-green, extremely fine-grained, waxy, non-calcareous clay with small black streaks and a few thin beds rich in organic matter. Four $0.5-1 \mathrm{~cm}$ thick, graded volcanic ash layers are present (fig. 8). Just above the two lowermost ash layers there is a black, $2-5 \mathrm{~cm}$ thick interval, rich in organic matter and especially rich in fish remains, including sharks teeth and coproliths.

The boundaries of Bed L 2 are sharp. The thickness at $\emptyset$ lst is $2.7 \mathrm{~m}$.

Distribution: See fig. 3 and table 1. There is no significant lateral variation in the lithology, as apparent from figs 9-14.

The constellation of two closely spaced ash layers below a black bed is easily recognized and forms an important marker within L 2. Apart from $\varnothing$ lst-Hinge, it is also found at $\emptyset$ rby, Albækhoved, Trelde and Røjle. At the two latter localities the third ash layer is also present, in a position similar to $\emptyset$ lst-Hinge.

The identity of this marker at various localities is confirmed by the biostratigraphy. Thus the latest occurrence in the Lillebælt Clay of the dinoflagellate Kisselovia coleothrypta and the first occurrence of Dracodinium pachydermum are between the second and the third ash layer in $\mathrm{L} 2$ at $\emptyset$ Ist and at the Lillebæit localities.

\section{3}

Red-brown, non-calcareous, extremely finegrained, waxy clay. Close to the middle a yellowish, partly carbonate-cemented and bioturbated layer is present. The thickness of the yellowish layer is up to $10 \mathrm{~cm}$, but locally it is only a thin streak. The thickness of L 3 at $\emptyset$ lst is $1.2 \mathrm{~m}$.
Distribution: See fig. 3 and table 1 . At $\emptyset$ rby no red-coloured interval corresponding to $B e d L 3$ is present between Beds L 2 and L 4 (fig. 9). However, no indications of a hiatus have been observed at the position where L 3 was expected and it is replaced by a greenish clay rather similar to Bed L 2. A concretionary band, as described from $\emptyset$ lst, is also found at Ørby.

At all other localities a red-coloured interval occurs between Beds L 2 and L 4. At the Lillebælt localities (figs 10,14 ) the red interval includes several green and yellowish clay layers. A thin, discontinuous ash layer - the uppermost one known in the Lillebælt Clay Formation - is present in $\mathbf{L} 3$ in the Lillebælt area. A bioturbated concretionary layer, similar to that from $\emptyset$ lst, is present at the base of Bed L 3 at Lillebælt, while it occurs within Bed $\mathrm{L} 3$ at $\mathrm{Al}$ bækhoved and Kongstrup.

\section{4}

Non-calcareous, extremely fine-grained, waxy clay. The lower $3 \mathrm{~m}$ are greenish, while in the upper $5 \mathrm{~m}$ greenish beds alternate with brownish beds. Layers rich in bioturbated carbonate concretions occur approximately $1 \mathrm{~m}, 3.5 \mathrm{~m}$ and 5.5 $\mathrm{m}$ above the base. Concretions of barytes, usually $5-10 \mathrm{~cm}$ across, are sporadic.

The boundaries of the bed are sharp and the thickness at $\varnothing$ lst is approximately $8 \mathrm{~m}$.

Distribution: At Ørby and Albækhoved only the lower green part of Bed L 4 is exposed.

At the Lillebælt localities the lower part is slightly more greyish, while in the upper part brownish and greenish colours alternate, as at $\emptyset$ lst.

One or two almost continuous layers of carbonate concretions are present in the lower 0.5-1.5 $\mathrm{m}$ at the Kongstrup, Albækhoved and Lillebælt localities.

In Viborg 1 the thickness is uncertain since the upper boundary was not cored. The maximum possible thickness is shown in table 1 .

The biostratigraphically important dinoflagellate Eatonicysta ursulae, which appears in the lower part of the Røsnæs Clay, disappears in the lower part of Bed L 4 at all the localities examined. 


\section{5}

Dark greenish grey, slightly calcareous clay with a small amount of silt. Some layers in the middle of the bed are reddish and rich in glauconite. In the upper $2.5 \mathrm{~m}$ there are three layers with relatively large carbonate concretions. A few similar concretions occur at various levels below, and there are a few barytic and smaller phosphatic concretions, sometimes containing well preserved fossil crabs. The boundaries are sharp and the thickness at $\emptyset$ lst is $16 \mathrm{~m}$.

Distribution: See fig. 3 and table 1. There is no significant lateral variation in lithology. Outcrops of $L 5$ and $L 6$ are particularly subject to sliding, and sections are usually small and shortlived.

\section{6}

Brownish grey, calcareous clay. Thin horizons of brown and green, non- to slightly calcareous clay are present about $2 \mathrm{~m}$ below the top. The lowermost $5 \mathrm{~m}$ include numerous layers rich in carbonate concretions. The boundaries are sharp; the lower boundary is marked by a concretionary horizon and by a change in colour. The upper boundary is placed at the colour change to the lighter grey Søvind Marl Formation above. The thickness at $\emptyset$ lst is $8.8 \mathrm{~m}$.

Distribution: Only very small, usually temporary exposures are known from the Lillebælt area (fig. 14) and detailed information on lithological variation is therefore unavailable. From observations in boreholes at the old Lillebælt bridge (Mertz 1928), the LB 38 (Dinesen 1965) and Viborg 1 boreholes (Flagler 1940) it may be concluded that a sequence of clay with variable carbonate content and colour, referred to Bed L 6, is present above the slightly calcareous clay of Bed L 5 .

\section{Søvind Marl Formation}

The name is derived from the village of Søvind (fig. 2), north of Horsens Fjord. In the Søvind area, the Søvind Marl Formation was previously exposed in several marl pits; most of these are now abandoned and inaccessible.

Previous and present use of the name:

The name Søvind Marl was introduced as a strat- igraphic term by Andersen (1938a). Dinesen et al. (1977) excluded the lower part of the Søvind Marl which belongs in the Pseudohastigerina wilcoxensis foraminiferal zone, and referred it to their 'Transition strata, Lillebælt Clay/Søvind Marl". In the present work we use the name Søvind Marl Formation in accordance with the original description of Andersen (1938a), i.e. including the similar deposits belonging in the Pseudohastigerina wilcoxensis Zone.

\section{Lithology:}

The Søvind Marl Formation is a light grey to almost white, very fine-grained marl or calcareous clay. The carbonate content is frequently 20 $50 \%$ and may be as high as $70 \%$. The Søvind Marl Formation includes thin beds of darker coloured, non- or slightly calcareous clay. Apart from these layers, bedding is indistinct. Burrows (mainly Zoophycos) are present and are most conspicuous where they penetrate the darker, less calcareous beds mentioned above. A few levels within the Søvind Marl Formation are rich in sand-sized glauconite. Both carbonate and barytes concretions occur, but are not common.

\section{Thickness:}

The thickness varies from $4.3 \mathrm{~m}$ at $\emptyset$ lst to $50.4 \mathrm{~m}$ in Viborg 1 (table 1).

\section{Lower boundary:}

The only outcrops showing the lower boundary of the Søvind Marl Formation are the clay pits at $\emptyset$ lst and Hinge (fig. 7). The boundary sequence is also described from the Viborg 1 and LB 38 boreholes by Flagler (1940) and Dinesen (1965) respectively. Neither of the boreholes have a complete recovery, but it seems that layers with a variable carbonate content (belonging to Bed L 6 of the Lillebalt Clay Formation) underly the Søvind Marl Formation, as at $\varnothing$ lst.

\section{Upper boundary:}

The uppermost Søvind Marl Formation is diachronous (Dinesen 1965, 1972) and the upper boundary is marked by a regional hiatus, which is assumed to include the Eocene-Oligocene boundary (fig. 4). The oldest overlying strata are probably the basal Grundfør Member of the Viborg Formation which has been defined by Christensen \& Ulleberg $(1973,1974)$. The Viborg For- 
mation is present north of the Søvind area, and the age of the lower part is Early Oligocene NP 21/NP 22 Zone (Mikkelsen 1975). Today the boundary between the Søvind Marl Formation and the Viborg Formation is only well exposed in Ølst clay pit and maybe in the coastal cliff at Moesgård Strand, south of Aarhus (table 2). At both localities the Søvind Marl Formation is overlain by a glauconitic, darker and coarser clay deposit. Until recently the boundary was also exposed in the clay pit at Grundfør (table 2) where the upper $0.5 \mathrm{~m}$ of the Søvind Marl Formation was intensely burrowed. The $\mathrm{cm}$-thick, branching burrows are filled with a dark matrix derived from the overlying Grundfør Member.

From the Søvind area and southwards the Søvind Marl Formation is overlain by the MiddleLate Oligocene Brejning Member (Dinesen 1965). The Brejning Member is the basal part of the Vejle Fjord Formation (Larsen \& Dinesen 1959) and is a dark, glauconitic clay, rich in molluscs. Burrows extend $0.5-1 \mathrm{~m}$ down into the Søvind Marl Formation. The boundary is well exposed at Nørre Vissing (table 2). This sequence is noteworthy because this far north the Viborg Formation is generally found between the Søvind Marl Formation and the Vejle Fjord Formation (Friis et al. 1981). Until a few years ago the boundary was also exposed in the abandoned marl pit on Galgehøj (table 2) near Horsens. At Bøgeskov, Trelde (fig. 2), small sections of Søvind Marl Formation are exposed on the beach, overlain by the Vejle Fjord Formation which is subject to sliding.

\section{Distribution:}

The Søvind Marl Formation is absent in the most westerly part of Limfjorden where a hiatus, which includes most or all of the Eocene (fig. 4), can be demonstrated at Silstrup "Sydklint", in the Klovbakker mo-clay pit at Sundby (NW Mors), on Fur, and in the Harre borehole (Gry 1979, Heilmann-Clausen 1982, Friis \& Nielsen 1980).

According to Flagler (1940) the Søvind Marl Formation in the Viborg 5 borehole is greatly reduced in thickness, and the lithology is atypical. The section is rich in glauconite and includes different coloured beds with a variable carbonate content.

South of Limfjorden the Søvind Marl Forma- tion is known throughout the distribution area of the Danish Eocene (fig. 1).

Northern Germany: A sandy, glauconitic facies is present in most of the Middle and Late Eocene in the Hamburg area (Hinsch 1974). The sandy deposits wedge out to the north and are replaced by marls in Schleswig. The marls are here included in the Søvind Marl Formation.

Age:

Thiede et al. (1980) assign the lower part of the Søvind Marl Formation of the Viborg 1 borehole to the Middle and Late Eocene (NP Zones 16, 17 and 19 , while the NP 18 Zone is either very thin or missing). In the upper part of the Søvind Marl Formation in Viborg 1 the NP zonation is uncertain, and the Eocene-Oligocene boundary is placed with some doubt at the boundary between the Søvind Marl Formation and the Viborg Formation. The exact position of the boundary between the Lillebælt Clay Formation and the Søvind Marl Formation in Viborg 1 is unknown because it occurs in an $8 \mathrm{~m}$ thick uncored interval. The lowermost sample of the Søvind Marl Formation above the uncored part belongs to NP 16, while the Lillebælt Clay Formation below is assigned to NP 15. Samples from the type area of the Søvind Marl Formation are all assigned to the NP 16 Zone (Thiede et al. 1980).

Samples from Skansebakken, at Vejle Fjord (table 2) and from Ørby are assigned to the NP 15 Zone (Thiede et al. 1980). They are referred to the Lillebælt Clay by these authors, but were nevertheless characterized as samples of pale grey marl by Perch-Nielsen (1971- 8). The marl from these two localities is here included in the Søvind Marl Formation.

The upper boundary of the Søvind Marl Formation is highly diachronous as shown on the basis of foraminifera by Dinesen et al. (1977), and confirmed by the NP zonation cited above (fig. 4). The Søvind Marl Formation includes successively younger strata when traced from Lillebælt to Søvind and further to Viborg.

\section{Type area:}

The Søvind area.

No specific type section has been established. In the marl pits at Søvind and Toftum (fig. 2, table 2) parts of the formation are exposed, but neither the lower nor the upper boundary can be seen. 

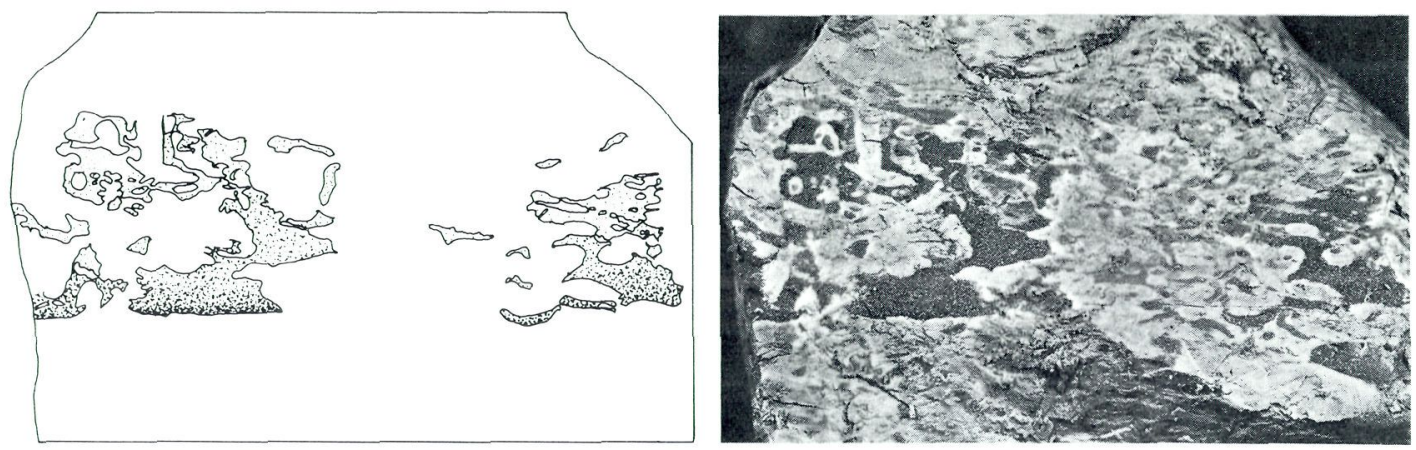

Fig. 15. Volcanic ash layer in the Holmehus Formation at Ny Klitgård. Similar highly bioturbated ash layers occur in the Røsnæs Clay Formation. The left figure shows undisturbed parts of the ash layer with graded bedding. $\times 1$.

\section{Reference sections:}

See table 1. A complete section is visible only at Ølst (fig. 7). The sections at Nørre Vissing and maybe Moesgård include the upper boundary.

Volcanic ash layers in the Holmehus, Røsnæs Clay and Lillebælt Clay Formations

Andersen (1937a: 24) described some conspicuous layers in the Røsnæs Clay Formation as "strange verdigris-coloured layers with lighter coloured spots, which give them a spongy appearance" (translated from Danish by the authors). He did not, however, recognize them as ash layers. They were shown to be argillized volcanic ash layers by Gersner (1980, unpublished thesis) and his conclusions have been used by Knox \& Morton (1983) and Malm et al. (1983). The evidence for a volcanic origin has not been published previously and is therefore briefly summarized below:

1. Graded bedding has been recognized in some layers (figs 15-17); this is frequently masked by argillization.

2. Layers as thin as $1 \mathrm{~cm}$ have been individually identified at localities more than $100 \mathrm{~km}$ apart.

3. The fraction larger than $33 \mu \mathrm{m}$ consists, apart from plagioclase grains, of numerous rounded, varicoloured grains with an indistinct, blurred appearance, similar to grains of basaltic glass from the Ølst Formation and also similar to the description of basaltic glass by Waagstein \& Jóhansen (1968) and Seibertz \& Vortisch (1979).

4. In the clay fraction the smectite content is 80$90 \%$ in contrast to the beds just above and below where it may be as low as $15-30 \%$.
5. The layers have sharp boundaries and the over- and underlying beds are normally identical, but quite different from the episodic layer in between.

6. The Ti-content shows a distinct increase in the layers, which supports the assumption of a basaltic ash fall similar to the Ti-rich basaltic ash layers in the $\varnothing$ lst and Fur Formations described by Pedersen et al. (1975).

The ash layer (fig. 15) in the Holmehus Formation is the oldest firm evidence of volcanism in the Danish Tertiary. Biostratigraphically it can be correlated with the Phase 1 volcanism of Knox \& Morton (1983) known from the central and northwestern North Sea. This volcanism took place during the Alisocysta margarita Zone (equivalent to the Ceratiopsis speciosa Zone which includes the Holmehus Formation).

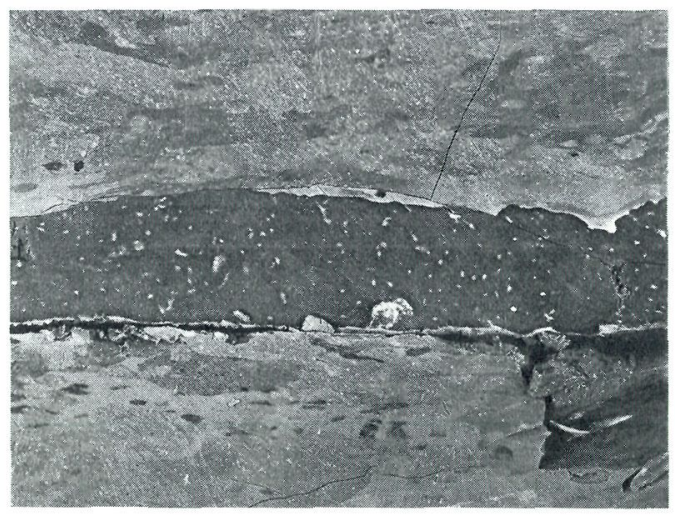

Fig. 16. Volcanic ash layer in the Røsnæs Clay Formation (uppermost layer in R 5) at $\varnothing$ lst. The layer is moderately bioturbated. $\times 0.8$. 


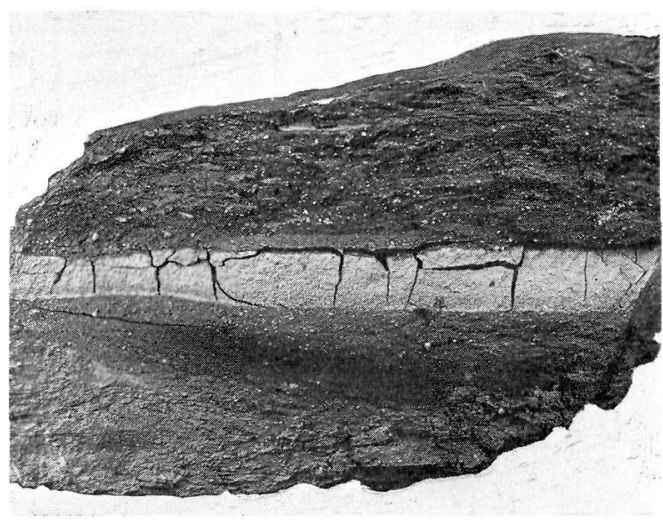

Fig. 17. Volcanic ash layer in the Lillebælt Clay Formation (second layer in L 2) at Ølst. Dessication cracks in the dried sample are confined to the ash layer and reflect the high smectite content. The layer is not bioturbated and displays graded bedding. $\times 1$.

The numerous thin ash layers in the Røsnæs Clay Formation and lower Lillebælt Clay Formation (figs 16,17 ) probably represent a late phase of the dominant volcanic event producing the numerous ash layers in the underlying upper part of the $\varnothing 1 s t$ Formation. Simultaneous volcanic activity in the Early Eocene has been reported from the North Sea by Jacqué \& Thouvenin (1975), Harrison, Knox \& Morton (1979) and Knox \& Morton (1983).

\section{Petrography and geochemistry}

Clay mineralogy, grain size and geochemical analyses were carried out on most of the formations. Only average values are included on the diagrams (figs 18-20), as the parameters usually show little or no variation within the individual members or beds.

The clay fraction $(<2 \mu \mathrm{m})$ was analysed by $\mathrm{X}$ ray diffraction using $\mathrm{Co}-\mathrm{K} \alpha$ radiation filtered by a graphite monochromator. Untreated oriented samples were analysed and were subsequently analysed after treatment with ethylene glycol and after heating to $500^{\circ} \mathrm{C}$. Semiquantitative determination of the clay mineralogy was achieved using the method described by Tank (1963) and Biscaye (1965). Clay minerals other than smectite, illite and kaolinite were only present in negligible amounts.

The chemical analyses were carried out by atomic absorption except for carbonate content , which was determined by combustion in an induction furnace.

The clays are generally characterized by large amounts of smectite, with a minor content of illite. Kaolinite is a minor component in sediments older than the Røsnæs Clay Formation. The regional distribution of clay minerals in four selected units, and their thicknesses, is shown on fig. 18.

Ølst Formation, the Værum Member (fig. 18a): The smectite content is very high and the kaolinite content very low. Deposits of volcanic origin are generally considered to be the most important source for smectite, and in this case the smectite was probably derived from weathering and alteration of volcanic products from the numerous eruptions during this period.

Røsnæs Clay Formation, Bed R 5 (fig. 18b): To the north and northwest the smectite content is still predominant, but to the south-east the contents of illite and especially kaolinite increase at the expence of smectite, probably because of the supply of kaolinite from more southerly land areas less influenced by volcanism.

Lillebælt Clay Formation, Bed L 3 (fig. 18c): The mineralogical pattern shown on the diagram is representative for Beds L 2, L 3 and the lower part of $\mathrm{L} 4$. In the northwestern area smectite no longer dominates, and the smectite content is further diminished to the south-east. Illite increases to the south-east, whereas the kaolinite content is fairly constant in the two regions.

Lillebælt Clay Formation, Bed L 5 (fig. 18d): The pattern returns to one dominated by smectite at the L 4/L 5 boundary. A possible explanation for the source of this assemblage may be erosion of (re)exposed areas rich in volcanic products or smectite (e.g the Ølst/Fur Formations or their equivalents).

The vertical variation in grain size and other parameters from the Ølst area and from the Albækhoved - northern Lillebælt area are presented on figures 19 and 20, respectively. The Lillebælt Clay Formation is extremely finegrained with almost $90 \%$ in the clay fraction and little or no sand. The other formations are somewhat coarser, but still very fine-grained clays. Most of the sand-sized material consists of various biogenic remains and authigenic particles such as clay aggregates and glauconite.

The Fe and Mn content (figs 19, 20) in general, 


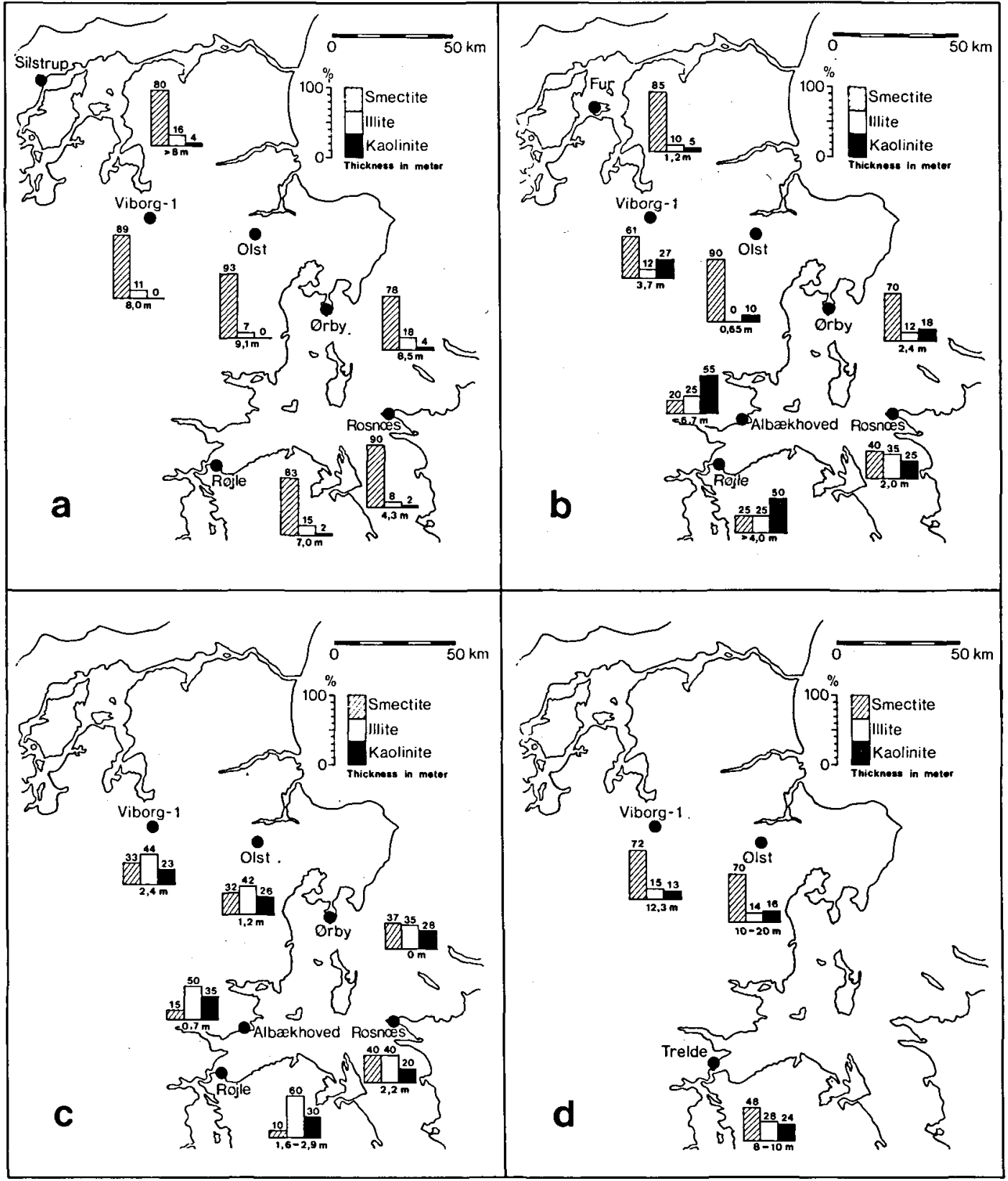

Fig. 18. Clay mineral distribution and thickness of a) Værum Member, Ølst Formation, b) Bed R 5, Røsnæs Clay Form., c) Bed L 3 , Lillebælt Clay Form., d) Bed L 5, Lillebælt Clay Formation.

matches the variation in colour; greenish units having significantly less of these elements than reddish units. This pattern is seen in the upper Røsnæs Clay and the lower Lillebælt Clay. Contrary to this, the amount of organic matter and pyrite is higher in the greenish than in the reddish units. These variations in the amount of $\mathrm{Fe}, \mathrm{Mn}$ and organic matter may indicate more intense reducing conditions during deposition of the greenish beds than during deposition of the reddish ones. During reduction periods, some $\mathrm{Fe}$ and $\mathrm{Mn}$ may have been mobilized and removed. 


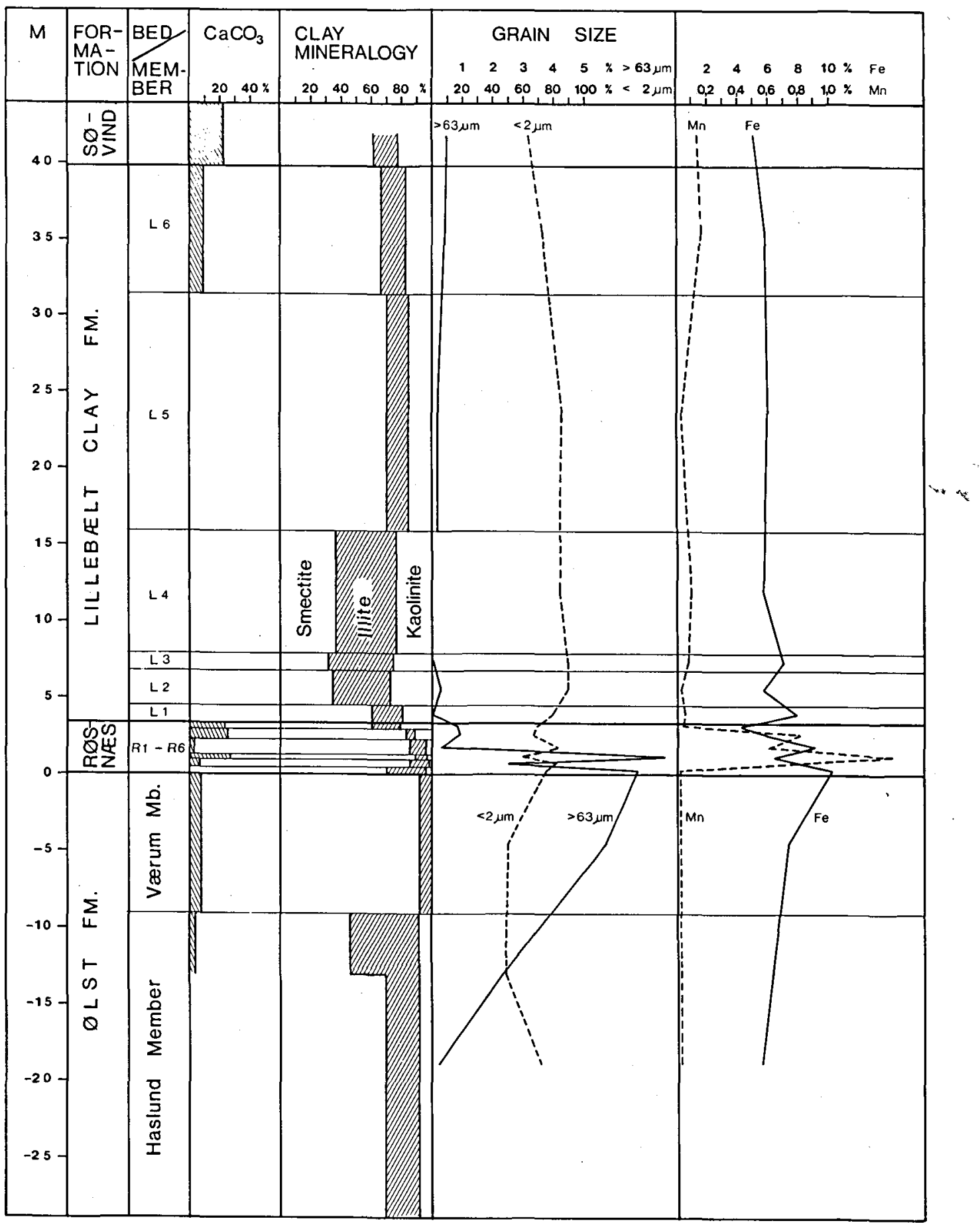

Fig. 19. Clay mineralogy, grain size distribution and chemical composition of uppermost Paleocene and Eocene sediments in the Ølst area. 


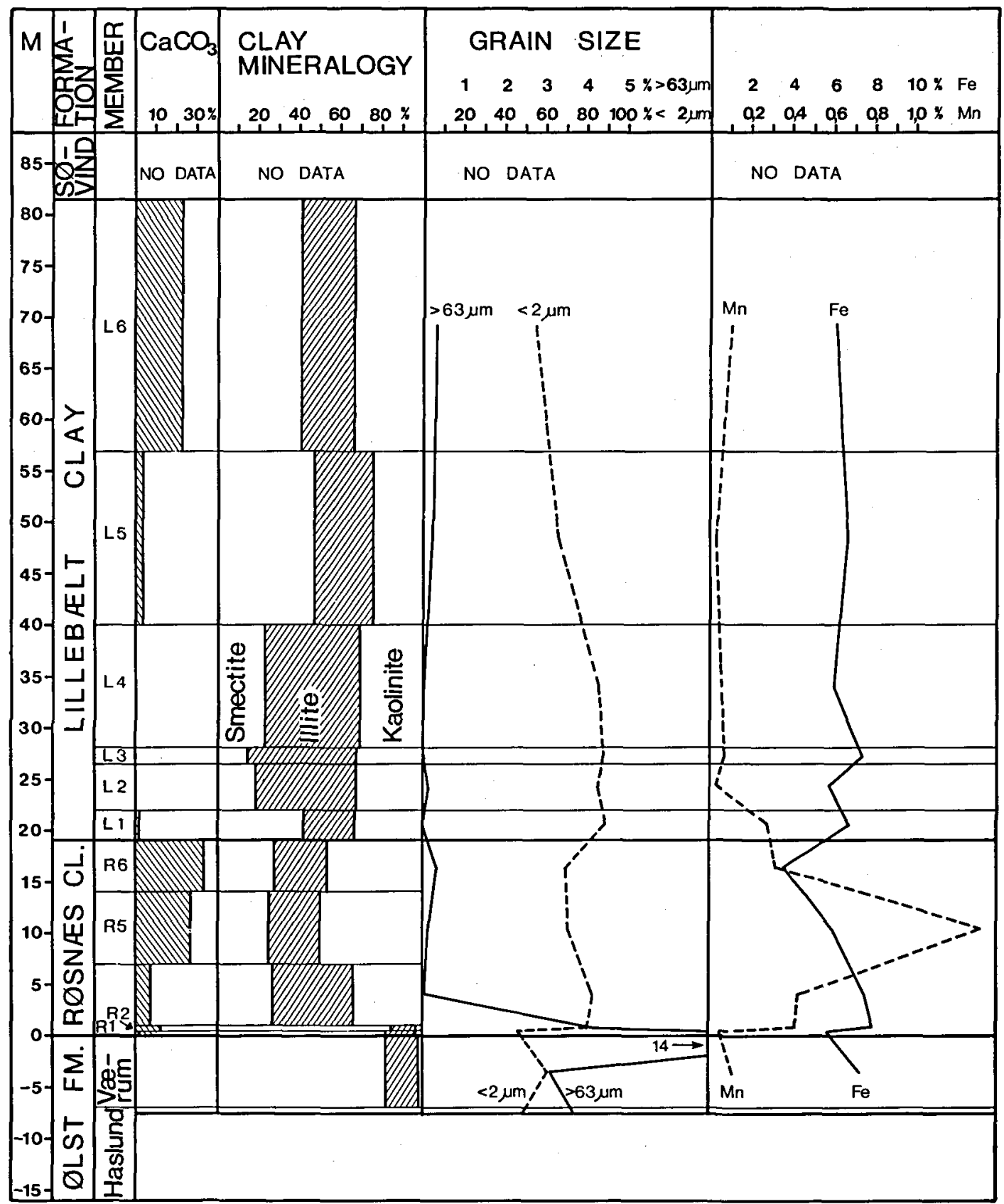

Fig. 20. Clay mineralogy, grain size distribution and chemical composition of uppermost Paleocene and Eocene sediments in the Albækhoved-northern Lillebælt area.

Thickness variation and structural setting

The uppermost Paleocene and Eocene deposits are relatively thin, about $100 \mathrm{~m}$, on the Ring- købing - Fyn High and towards the Fennoscandian Shield, where the thickness is only $50 \mathrm{~m}$ (Dinesen et al. 1977). South of the Ringkøbing Fyn High the thickness increases to about $200 \mathrm{~m}$ near the German border. In central Jutland 
(structurally belonging to the Danish Embayment) the thickness increases to at least $150 \mathrm{~m}$.

These variations in thickness were more than likely controlled by larger subsidence within the Danish Embayment and minor subsidence near the Fennoscandian Shield and on the Ringkøbing - Fyn High. Subsidence on the Ringkøbing - Fyn High seems to have been achieved through intermittent phases of uplift and subsidence. Thus the absence of both the lower subzone of the $A$. $h y$ peracanthum Zone (fig. 5) and of Eocene younger than the NP 15 Zone (possibly also south of the High) indicates uplift with non-deposition or erosion in the latest Paleocene and in the Middle Eocene to Oligocene/Miocene.

Local hiati in the Eocene of northwestern Jutland (fig. 4) are probably caused by movement of the Zechstein salt structures in this area.

\section{Depositional environment}

During the Early Tertiary a semi-enclosed shelfsea covered most of the present North Sea, Denmark and various parts of Northern Germany. In the Early Paleocene (Danian) almost exclusively pelagic and bryozoan limestones were deposited. From the end of the Danian until today however, clastic sediments have been deposited. In the Palaeogene these sediments are mainly clays and silts. This major shift in sedimentation was caused by an eustatic sea level fall in the Late Paleocene, associated with Laramide tectonism including the uplift of the Shetland Platform (Ziegler 1981).

The marine clays deposited in the Danish area during the Late Paleocene and Eocene include the finest-grained deposits known from the North Sea Basin. The fine grain size, graded ash beds, lamination and Zoophycos - Chondrites ichnofacies all indicate a water depth well below wave base.

The many vertical changes in lithology, but lateral uniformity of the lithological units, as described in the section on lithostratigraphy, show that widespread, often marked, changes in the depositional environment took place. The individual formations are interpreted below.

\section{Holmehus Formation}

This represents the first phase of very fine- grained clay sedimentation in the Danish area. Illies (1949) and Spjeldnæs (1975) suggested that the remarkable absence of any coarse clastic particles in deposits so close to the Scandinavian Shield may have resulted from the presence of a thick vegetation cover on a landmass of low relief with only a moderate run-off directed to this area.

The Holmehus Formation was deposited in a fully marine environment and the bottom waters were moderately to well oxygenated. This interpretation is supported by the presence of a diverse agglutinated fauna of benthonic foraminifera together with burrows of Zoophycos and Chondrites and by the red colour in some beds of the formation. Furthermore, only a small amount of organic matter is present and it consists mainly of components which are resistant to oxidation (inertinite particles) and corroded dinoflagellate cysts. Oxidation of the organic matter is regarded as a primary feature. The sediment is impermeable and recent oxidation is prevented even in outcrops.

\section{$\emptyset$ lst and Fur Formations}

The boundary between the Holmehus Formation and the overlying Ølst Formation is sharp and the difference in the lithology and fossil content show a marked change in the depositional environment. The presence of glauconite indicates that the boundary probably coincides with a period of submarine non-deposition.

The oldest part of the Ølst Formation, a thick laminated clay sequence devoid of evidence for benthonic life, was deposited over a long period when anoxic conditions prevailed in the bottom waters. The laminae (fig. 21) indicate water depths below wave base. Correlation of this interval with the similar Sele Formation and Unit E of Knox, Morton \& Harland (1981) confirms the presence of anoxic conditions across most of the North Sea Basin, as pointed out by Knox \& Harland (1979).

The more variable lithology of the upper part of the Ølst Formation and in the equivalent Fur Formation (including both laminated and bioturbated intervals) indicates an alternation between anoxic and low-oxygenated periods. Pedersen (1981) described this in detail for the Fur Formation. 


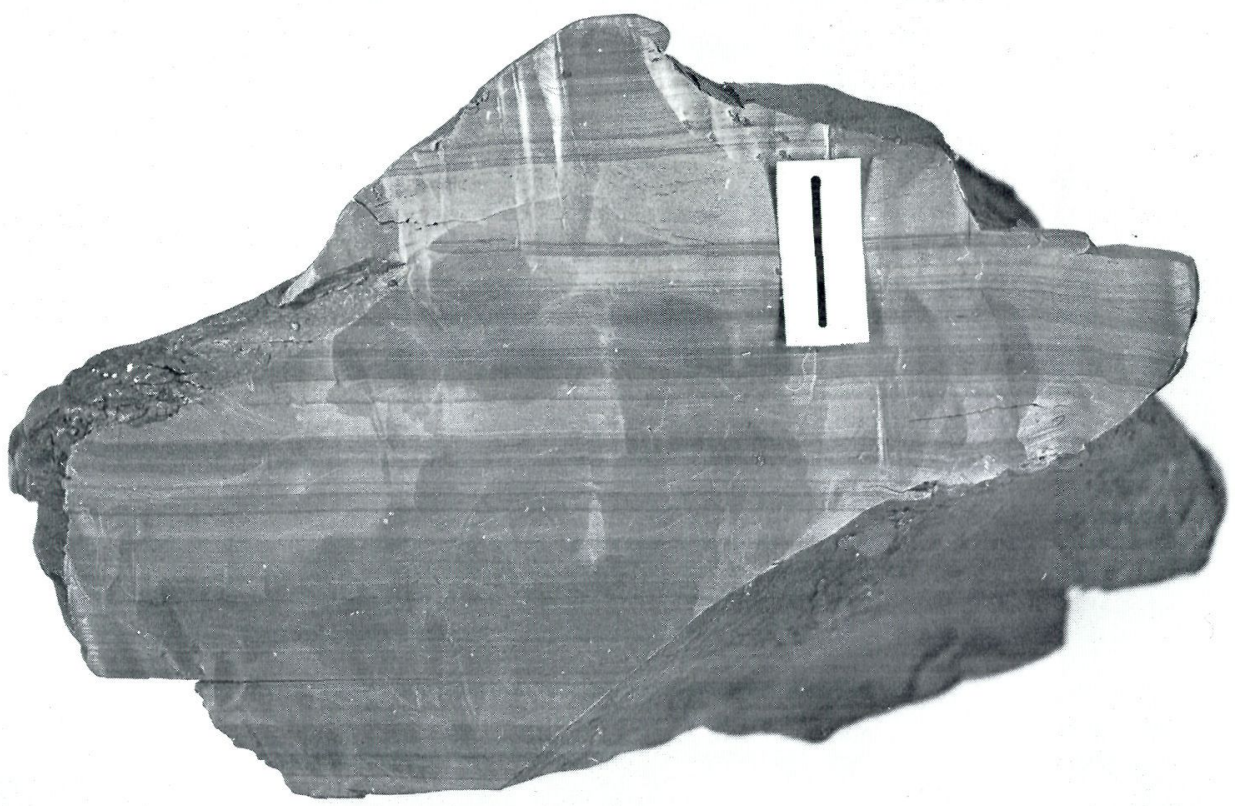

Fig. 21. Ølst Formation at the type locality. A sample showing the undisturbed lamination which characterizes the lower part of the formation. Length of bar: $2 \mathrm{~cm}$.

An increased amount of clastic silt particles in the Ølst Formation seems to reflect the regressive conditions which occurred at that time in northwestern Europe. Deposits of this age include the marginal marine and terrestrial Woolwich and Reading Beds in England, and the Upper Landenian and Sparnacian deposits in Belgium and Northern France.

It is likely that the salinity was lowered during deposition of the anoxic clays over the whole of the North Sea Basin as proposed by Knox et al. (1981). This is supported by the presence of the low-diversity dinoflagellate assemblage dominated by Apectodinium (lower subzone of the $A$. hyperacanthum Zone, fig. 5). This assemblage is also present in the lagoonal-continental Sparnacian and Landenian deposits (Gruas-Cavagnetto 1967, De Coninck 1972). The frequent occurrence of silicoflagellates in the Fur Formation (Perch-Nielsen 1976) however, probably excludes a salinity of below $20 \%$.

Bonde (1979) interpreted the development of a local diatomite facies - the Fur Formation - as the result of coastal upwelling, which occurred in an extensive zone stretching from the western Limfjord out to the northwest, thereby fitting it in with a detailed circulation model he proposed for the North Sea. This model was questioned by Pedersen (1981) and Pedersen \& Surlyk (1983) who suggested that the diatomite deposition was caused by more local upwelling. According to these authors, the diatomite was deposited in, or close to, a local depression in the sea floor. This depression resulted from halokinesis in the area.

The existence of thick and abundant ash layers in the upper part of the Ølst and Fur Formations shows that the most intensive volcanism in the Tertiary North Sea Basin must have taken place during the deposition of these units. This volcanism was probably caused by crustal tension associated with the opening of the Northern Atlantic Ocean (Knox \& Morton 1983). The large amount of smectite in the Late Paleocene and Eocene sediments is believed to be derived mainly from weathering of pyroclastic rocks, resulting from this volcanism. 


\section{Røsnæs Clay Formation}

In the western Limfjord area the Knudshoved Member forms the basal part of the Røsnæs Clay Formation. Sedimentation was almost continuous here from the deposition of the diatomaceous Fur Formation, through to the sedimentation of the Røsnæs Clay Formation.

In other parts of Denmark the Knudshoved Member is absent, and a hiatus is recognized both biostratigraphically and tephrachronologically between the Ølst and the Røsnæs Clay Formations. As the Ølst Formation at most localities terminates just above ash layer +130 , it seems that practically no erosion was associated with this phase of non-deposition. (An exception is Røsnæs, where the uppermost ash layer is +103 .) There is no evidence for either shallow water conditions or subaerial exposure. Rather the Zoophycos burrows, which penetrate the boundary, and the very fine grain size of clastic particles in the initial layers above suggest a water depth well below wave base.

The change in facies at the boundary is dramatic, and marks a return to those conditions which prevailed during deposition of the Holmehus Formation. Thus a very low energy environment in the Røsnæs Clay Formation (persisting into the younger Eocene deposits) is apparent from the grain size. Evidence for a low sedimentation rate (Thiede et al. 1980) supports this interpretation.

The bottom water became well oxidized, and full marine conditions were established, as indicated by the mainly red colour of the sediment, the almost total absence of organic carbon and pyrite and the presence of rich foraminiferal faunas (both benthonic and planktonic) and a Zoophycos ichnofacies.

The shift to the Røsnæs Clay facies is biostratigraphically correlated with the early phases of the Ypresian transgression known elsewhere in the North Sea Basin.

The existence of many ash layers shows that volcanism was still important although clearly diminished since the main volcanic phase in the upper Ølst and Fur Formations.

\section{Depositional phases}

The unique lithological features of Beds $R 1$ to $R 6$ reflect individual depositional conditions that were widely distributed and to some extent changed isochronously and suddenly over most of the area investigated. Alterations in the marine circulation pattern affecting organic production and bottom water oxygenation has probably caused the changes.

A high glauconite content in Beds R 1 and R 2 may be explained by the existence of very low sedimentation rates.

A differentiation into various local facies ( $\mathrm{R} 3$, R 4 and R 5, see fig. 3) followed. These may have initially existed simultaneously. In the central part, where the production of foraminifera was very high, Bed R 3 was deposited. Elsewhere R 4 and R 5 sediments accumulated. Later the calcareous $\mathrm{R} 5$ facies covered the whole area.

The transition to almost white clay at the $\mathrm{R} 5 /$ $R 6$ boundary is practically synchronous everywhere, as indicated by the marker ash layer near the top of R 5 .

The organic-rich black band (fig. 22) in the middle of the white bioturbated Bed R 6 probably represents a short anoxic episode in an otherwise well oxidized bottom environment. The white colour of the clay around the black band was probably caused by a reduction and mobilization of the original iron content of the earlier red clay due to oxidation of organic matter in the black band. This interpretation is supported by the very low iron content of Bed $R 6$, compared to the beds below and above (figs 19, 20).

Lower and middle Lillebælt Clay Formation (Beds L 1 to L 5)

During this phase oxygen supply to the bottom waters was probably more restricted although only occasionally leading to anoxia. This is indicated by the paucity of burrows and by the higher amount of pyrite and organic matter. The change in environment is also evident from the ash layers: While many ash layers in the Røsnæs Clay Formation are of a spongy appearance due to the more intense bioturbation (figs 15,16 ), they are practically undisturbed by burrows in the Lillebalt Clay Formation (fig. 17). On the other hand, a sparse, but rather diverse benthonic macrofauna is known (mainly from washed-out specimens at coastal exposures). It includes crinoids, 


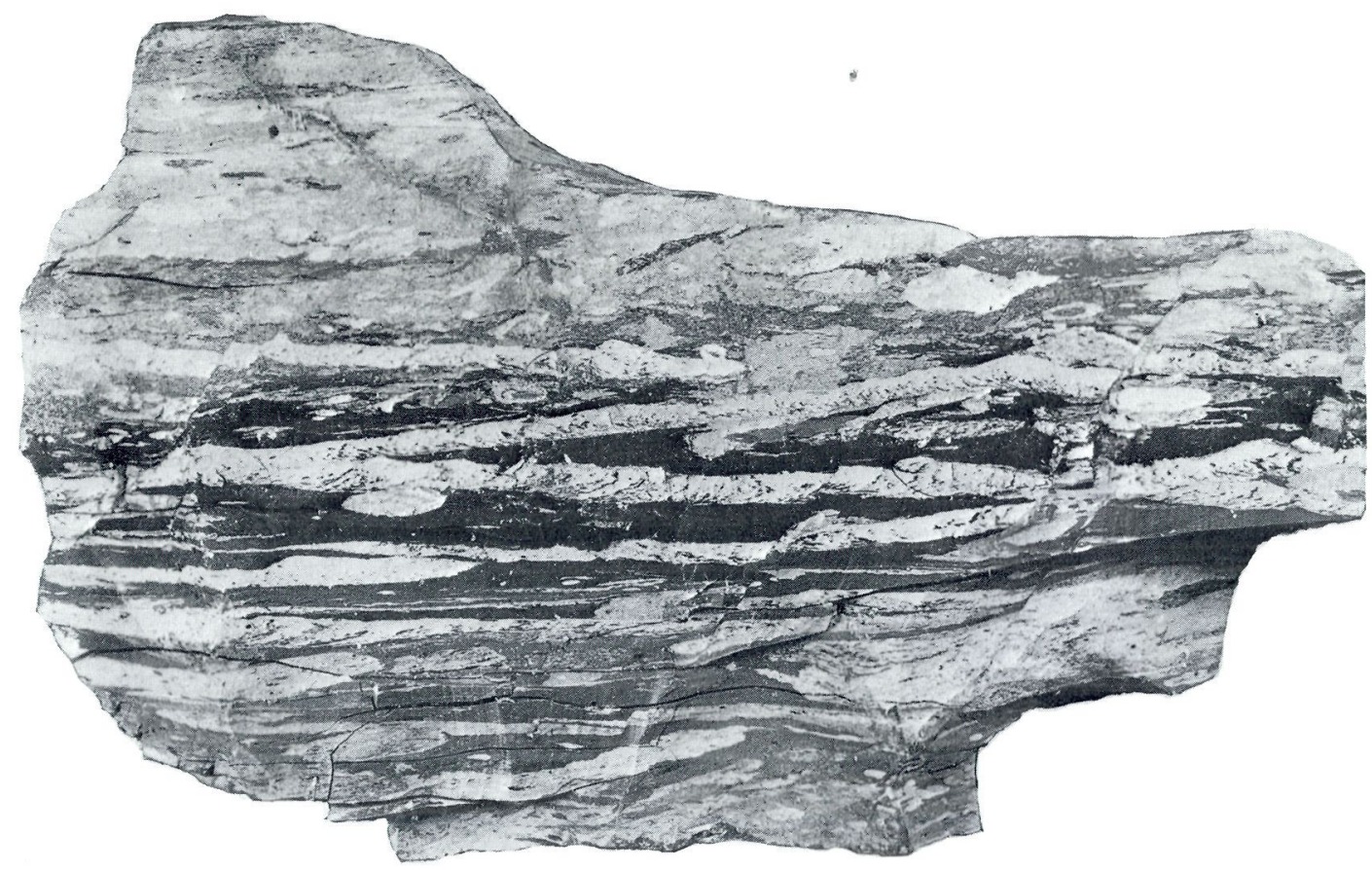

Fig. 22. Røsnæs Clay Formation, Bed R 6. A sample from Ølst, showing the black clay band crossed by Zoophycos burrows. The fill in the burrows is derived mainly from the white upper part of R $6 . \times 1,1$.

gastropods, bivalves, decapods and asteroids (Bonde 1968). Furthermore a well preserved assemblage of rather large, unusual trace fossils, preserved as carbonate concretions, occurs sporadically.

The non-calcareous lithofacies in this interval is associated with layers of carbonate concretions showing that carbonate was mobile during diagenesis.

\section{Depositional phases}

Widespread, sudden changes in the lithofacies are even more pronounced than in the Røsnæs Clay Formation and were again probably caused by alterations in the marine circulation pattern.

The major shift from a calcareous to a non-calcareous sedimentation at the base of Bed L 1 took place simultaneously in North Germany and Denmark - during the NP 12 Zone according to data in Thiede et al (1980) and Martini \& Müller (1971). The non-calcareous facies persisted into NP 14 where it was gradually replaced by a calcareous facies.
Frequent shifts between greenish and reddish beds probably reflect widespread fluctuations in the circulation pattern as suggested in the section on geochemistry. The boundaries of the reddish intervals (i.e. Beds L 1, L 3 and upper part of L 4) are almost isochronous as indicated by the tephrachronology and dinoflagellate stratigraphy. The highly bioturbated concretionary band in Bed L 3 possibly represents a brief incursion of well oxygenated bottom water leading to an episodic invasion of burrowing organisms.

The most stagnant environment of the Lillebælt Clay occurred in the lower part of Bed L 2. In particular, the sapropelic layer above the two ash layers represents a widely recognized anoxic episode. This (and the similar anoxic episode in Bed R 6) was probably caused by abnormally high marine organic production.

A probably isochronous and widely distributed event seems to have taken place at the L 4/L 5 boundary. Here a marked increase in the smectite content is recognized (further discussed in the section on petrography). 


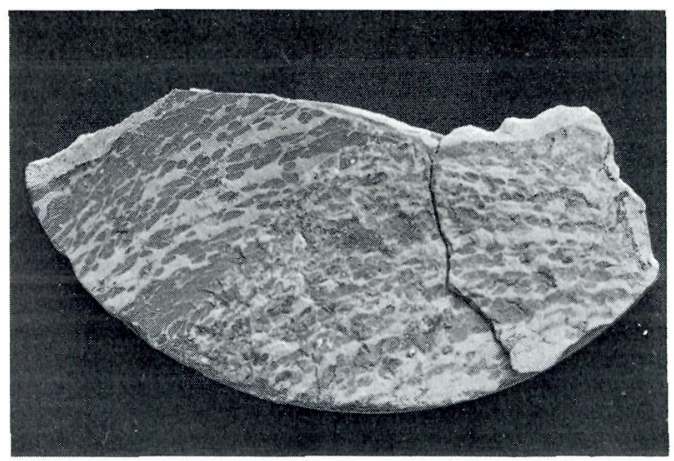

Fig. 23. Søvind Marl Formation from Viborg 1 borehole, a sample at depth $293.1 \mathrm{~m}$. Zoophycos burrow with fill of dark grey pellets in light coloured matrix. $\times 1.25$.

\section{Upper Lillebælt Clay Formation and Søvind Marl Formation}

The gradual change to a calcareous facies in bed L 6 and in the Søvind Marl Formation may mark the return of more oxygenated bottom waters as indicated by the frequent burrows (fig. 23). The abundance of calcareous microfossils indicates that the carbonate was less mobile than in the Lillebælt Clay Formation. The high proportion of planktonic foraminifera (Dinesen 1972) seems to indicate a rather deep shelf environment. Fine sand was transported into the basin's margin in North Germany from further south (Gripp 1964).

Acknowledgements. Material from the Viborg 1 and the LB 38 boreholes was kindly placed at our disposal by the former director O. Berthelsen, the Geological Survey of Denmark, and chief geologist A. Dinesen of the same institution. Financial support to parts of the work was received from the Danish Natural Science Research Council and from the Carlsberg Foundation.

We wish to thank everyone who assisted during the field work, during the processing of samples at the Geological Institute and the Palaeocology Department, Aarhus University, as well as in the preparation of this paper. In particular N. Bonde, C. Kronborg and K. Strand Petersen helped solving glacio-tectonic problems and working out the stratigraphy on many outcrops. The work was greatly stimulated by the interest and encouragement from N. Bonde, D. Ward and C. King. G. Grønlund and U. Viskum are thanked for typing several versions of the manuscript and L. Olesen for skilfully drawing the figures. Various stages of the manuscript were kindly commented on by N. Bonde, H. Friis, C. King, G. Krarup Pedersen, N. Spjeldnæs, F. Surlyk, E. Thomsen and D. Ward, R. Wilson and D. Penney improved the English text of the final manuscript.

\section{Dansk sammendrag}

Lithologien og udbredelsen af de danske aflejringer fra $\emptyset_{v r e}$ Paleocæn og Eocæn beskrives i detaljer. Kortlægningen støtter sig på de tilgængelige daglokaliteter og på tre kerneboringer (tabel 1 og 2).

Sedimenterne inddeles i seks formationer (figur 4 og 5). Den ældste var tidligere kendt som Paleocænt plastisk ler. Den er nu defineret som Holmehus Formationen. Sedimentet er ekstremt finkornet, grønt og rødligt ler. Alderen er Øvre Paleocæn $(\mathrm{Ce}$ ratiopsis speciosa dinoflagellat zonen). Holmehus Formationen hviler på kalkfattige, grå og siltrige lag, som endnu ikke er henført til nogen formation.

Holmehus Formationen overlejres af den siltholdige, grå leraflejring, der her defineres som Ølst Formationen. I den øvre del (Værum Led) indgår talrige vulkanske askelag. I den nedre del (Haslund Led) er askelagene langt færre. Den nederste del af Haslund Led er en op til femten meter tyk, fint lamineret enhed (fig. 21).

I det vestlige Limfjordsområde træder en askeførende diatoméaflejring ind i stedet for den del af $\varnothing$ lst Formationen som ligger over den laminerede del af Haslund Leddet (fig. 5). Diatoméaflejringen (tidligere kendt som moleret) er for nylig blevet opstillet som Fur Formationen af Pedersen \& Surlyk (1983).

$\varnothing$ lst og Fur Formationerne er henregnet til Øvre Paleocæn. Der skal dog tages et vist forbehold for alderen, idet der hersker generel usikkerhed om den præcise placering af PaleocænEocæn grænsen i Nordsøbassinets aflejringer.

De Eocæne aflejringer er, som Holmehus Formationen, ekstremt finkornede plastiske lerer. Den nederste del, som overvejende er rød og kalkholdig, henregnes til Røsnæs Ler Formationen. Den inddeles i et lokalt Knudshoved Led i Limfjordsområdet samt i en række vidt udbredte lag, der er benævnt R 1 til R 6 (figs 3, 8-14). Disse lag afviger fra hinanden især i farve og indhold af kalk, glauconit og organisk stof. De er overvejende af ringe tykkelse og kan følges over store afstande.

Røsnæs Ler Formationen overlejres af den Nedre?-Mellem Eocæne Lillebælt Ler Formation, som omfatter overvejende grønligt-gråligt, næsten kalkfrit ler. I den nederste del forekommer dog rødlige indslag, og i den øverste del er der lysere lag af kalkholdigt ler. Lillebælt Ler Formationen inddeles i seks lag, benævnt L 1 til L 6, der kan følges næsten uændret over hele det undersøgte område (figs 3, 8-14).

Over Lillebælt Ler Formationen følger hvide til lysegrå kalkholdige ler- og mergel aflejringer. Disse henregnes til Søvind Mergel Formationen. Alderen er Mellem til Øvre Eocæn; men kun i den centrale del af Jylland indgår lag af Øvre Eocæn alder (fig. 4) (Dinesen 1972, Dinesen et al. 1977). Søvind Mergel Formationen overlejres af mere grovkornede og mindre kalkholdige Oligocæne til Miocæne sedimenter tilhørende Viborg og Vejle Fjord Formationerne.

I Holmehus, Røsnæs Ler og Lillebælt Ler Formationerne er der påvist en række vulkanske askelag (figs 15-17). Lagene er identiske med de "mærkelige spanskgrønne lag" som S. A. Andersen beskrev i 1937. I enhederne R 5 til L 2 er de samme askelag fundet ved Lillebælt, Vejle Fjord, Ølst og Hinge samt på Røsnæs og Helgenæs (figs 8-14). Der er således etableret en askelags-kronologi i det tilsvarende tidsinterval.

Aflejringsmiljøet gennemgås. De mange bratte skift i lithologi, kombineret med en regional ensartethed af de enkelte formationer og lag viser, at en række pludselige, vidt udbredte ændringer fandt sted i aflejringsmiljøet. Det synes overvejende at være ændringer i det marine cirkulationsmønster i Nordsøen; men også ændringer i tilførslen af lermineraler har gjort sig gældende.

Fem større aflejringsfaser kan identificeres. De omfatter hver en formation (Ølst og Fur Formationerne er dog aflejret $i$ samme fase). Alle sedimenterne er marine eller brakke. Havbunden synes dog på intet tidspunkt at have været over bølgebasis.

Holmehus Formationen er aflejret under fuldt marine forhold, bundvandet var iltholdigt, og kun det fineste klastiske materiale blev tilført fra omliggende landområder. 
Efter ophold i sedimentationen, men stadig med vanddybder under bølgebasis aflejredes den laminerede nedre del af $\emptyset$ lst Formationen i et milj $\varnothing$ med iltfrit bundvand. Saliniteten var formentlig nedsat. Det noget grovere klastiske materiale, som indgår i Ølst Formationen, kan forklares ved de udpræget regressive forhold, som herskede i Nordvesteuropa i denne periode. Under aflejringen af øvre del af $\emptyset$ lst og Fur Formationerne tillod indslag af svagt iltholdigt bundvand lejlighedsvis gravende organismer at etablere sig. Den intensive vulkanisme, som resulterede i de talrige askelag, har forbindelse med spændinger $i$ jordskorpen opstået ved åbningen af nordatlanten.

Efter endnu et ophold $i$ sedimentationen $-i$ al fald uden for Limfjordsområdet - ændredes miljøet drastisk til forhold, der ligner dem, hvorunder Holmehus Formationen aflejredes. Forholdene er igen fuldt marine, og bundvandet er vel-oxideret, hvilket afspejles i Røsnæs Ler Formationens røde farve, i mangelen på organisk materiale og i de hyppige gravegange. Af lejringsforholdene var ekstremt rolige. Askelagene viser, at vulkanismen stadig var ret intensiv. Den aftog hurtigt i den følgende periode, hvor Lillebælt Ler Formationen aflejredes. På den tid synes ilttilførslen til bundvandet at være aftaget. Der var dog fortsat så megen ilt, at en sparsom bundfauna kunne eksistere. Aflejringsforholdene var stadig meget rolige. De bratte skift $i$ lithologien afspejler sandsynligvis omslag $i$ den marine cirkulation.

Under aflejring af øvre del af Lillebalt Ler Formationen og især af Søvind Mergel Formationen blev bundvandet igen mere iltholdigt. Gravende organismer blev hyppige (fig. 23). Efter aflejring af Søvind Mergel Formationen indtraf en regional afbrydelse i sedimentationen. Dette betød afslutningen på en periode i det danske Tertiær karakteriseret ved meget finkornede aflejringer.

\section{References}

Andersen, J. P. 1947: Den stribede cementsten i de danske eocane molerlag. Meddr dansk geol. Foren. 11 (2), 189196.

Andersen, L. J. 1958: Nye forekomster af eocane askelag ved Randers. Meddr dansk geol. Foren. 13, 449-470.

Andersen, N. M. 1982: A fossil water measurer (Insecta, Hemiptera, Hydrometridae) from the Paleocene/Eocene of Denmark and its phylogenetic relationships. Bull. geol. Soc. Denmark 30, 91-96.

Andersen, S. A. 1937a: De vulkanske Askelag i Vejgennemskaringen ved Ølst og deres Udbredelse i Danmark. Danm. geol. Unders. (2) $59,50 \mathrm{pp}$.

Andersen, S. A. 1937b: Et Vulkanomraades Livshistorie. Geol. Fören. Stockh. Förh. 59 (3), 317-346.

Andersen, S. A. 1938a: Oligocxnet ved Aas. Meddr dansk geol. Foren. 9 (2), 218-223.

Andersen, S. A. 1938b: Die Verbreitung der eozänen vulkanischen Ascheschichten in Dänemark und Nordwestdeutschland. Z. Geschiebeforsch. Flachldgeol. 14 (4), 179-207.

Andersen, S. A. 1944: Det danske Landskabs Historie second edition, vol. 1. 480 pp. Andersen \& Gøtterups Forlag, København.

Benda, L. 1972: The diatoms of the Moler Formation in Denmark (Lower Eocene). Beih. Nova Hedwigia, 39, 251-266.

Berggren, W. A. 1960a: Some Planktonic Foraminifera from the Lower Eocene (Ypresian) of Denmark and Northwestern Germany. Stockh. Contr. Geol. 5 (3), 41-108.

Berggren, W. A. 1960b: Biostratigraphy, Planktonic Foraminifera and the Cretaceous Tertiary boundary in Denmark and Southern Sweden. In: Int. Geol. Congress, XXI Session, Proc. part V, Copenhagen, 181-192.

Berthelsen, A. 1975: Geologi på Røsnæs. Varv Ekskursionsfører Nr. 3. 78 pp. Tidsskriftet Varv, Copenhagen.
Bettenstaedt, F. 1944: Neues aus der angewandten Mikropaläontologie (X) Nordwestdeutschen Paläozän und Eozän, Methodisches. Oel und Kohle 40, 77-87.

Bettenstaedt, F., Fahrion, H., Hiltermann, H. \& Wick, W. 1962: Tertiär Norddeutschlands. In: Leiffossilien der Mikropaläontologie. Gebrüeder Borntraeger, Berlin, 339378.

Biscaye, P. E. 1965: Mineralogy and sedimentation of recent deep-sea clay in the Atlantic Ocean and adjacent seas and oceans. Bull. geol. Soc. Am. 76, 803-832.

Bonde, N. 1966: The fishes of the Mo-clay Formation (Lower Eocene). Meddr dansk geol. Foren. 16, 198-202.

Bonde, N. 1968: Nyligt fundne fossiler fra det "plastiske ler«. I. Invertebrata. Meddr dansk geol. Foren. 18 (1), 148-151.

Bonde, N. 1973: Fiskefossiler, diatomiter og vulkanske askelag. Dansk geol. Foren. Arsskr. 1972, 136-143.

Bonde, N. 1974: Palaeoenvironments as indicated by the "Moclay Formation" (Lowermost Eocene of Denmark). Tertiary Times 2 (1), 29-36.

Bonde, N. 1979: Palaeoenvironment in the "North Sea" as indicated by the fish bearing Mo-clay deposit (Paleocene/Eocene), Denmark. Meded. Werkgr. Tert. Kwart. Geol. 16 (1), 3-16.

Bonde, N. 1982: Teleostei (bony fish) from the Paleocene of the Norwegian North Sea Drillings. Norsk Geologisk Tidsskrift 62, 59-65.

Buch, A. 1961: Lidt om mikrofossiler i plastisk ler i Nordjylland. Meddr dansk geol. Foren. 14, 461.

Bøggild, O. B. 1903: Vulkansk Aske i Moleret. Meddr dansk geol. Foren. 2 (9), 1-12.

Bøggild, O. B. 1918: Den vulkanske Aske i Moleret samt en Oversigt over Danmarks aldre Tertiærbjærgarter. Danm. geol. Unders, (2) 33, $159 \mathrm{pp}$.

Caro, Y. 1973: Contribution a la connaissance des dinoflagellés du Paléocène-Éocène des Pyrénées espagnoles. Rev. Espan. Micropal. 5, 329-372.

Christensen, L. \& Ulleberg, K. 1973: Sedimentology and micropalaeontology of the Middle Oligocene sequence at Sofienlund, Denmark. Bull. geol. Soc. Denmark 22 (4), 283305.

Christensen, L. \& Ulleberg, K. 1974: Sediments and foraminifers of the Middle Oligocene Viborg Formation, Denmark. Bull. geol. Soc. Denmark 23 (1-2), 109-117.

Clausen, H. 1932: Røntgenografiske Unders $\emptyset$ gelser af danske Lerarter. Meddr dansk geol. Foren. 8 (2), 167-174.

Costa, L. I. \& Müller, C. 1978: Correlation of Cenozoic dinoflagellate and nannoplankton zones from the NE Atlantic and NW Europe. Newsl. stratigr. 7 (2), 65-72.

De Coninck, J. 1972: Application stratigraphique des microfossiles organiques dans l'Yprésien du Bassin Belge. Bull. Soc. belge Géol., Paléont., Hydrol. 81 (1-2), 1-11.

Deegan, C. E. \& Scull, B. J. 1977: A standard lithostratigraphic nomenclature for the Central and Northern North Sea. Rep. Inst. Geol. Sci. 77/25, 36 pp.

Dinesen, A. 1965: Boringen $L B 38$ pả Lyngs Odde. 83 pp. Danm. geol. Unders. (unpublished report).

Dinesen, A. 1971: Pleistocene and Eocene in Rønde No. 1. In: Rasmussen, L. B. (ed.). The deep test well Rønde No. 1 in Djursland, Denmark. Danm. geol. Unders. (3) 39, 47-49.

Dinesen, A. 1972: Foraminiferselskaber fra de jyske eocæne formationer. Dansk geol. Foren. Ársskr. 1971, 70-78.

Dinesen, A. 1973: Eocene in Nøvling No. 1. In: Rasmussen, L. B. $(e d$.$) . The Deep Test Well Nøvling No. 1, in Central$ Jutland, Denmark. Danm. geol. Unders. (3) 40, 71-81.

Dinesen, A., Michelsen, O. \& Lieberkind, K. 1977: A survey of the Paleocene and Eocene deposits of Jylland and Fyn. Danm. geol. Unders. Ser. B 1, 15 pp.

Elbert, J. \& Klose, H. 1904: Kreide und Paleocän auf der Greifswalder Oie. VIII. Jahresber. Geogr. Gesellsch. Greifswald. 
Elliott, G. F. 1971: Eocene volcanics in south-east England. Nature (phys. Sci.) 230, p. 9.

Eriksen, K. 1937: En foreløbig Meddelelse om Tertiæret ved Brejning på Sydsiden af Vejle Fjord. Meddr dansk geol. Foren. 9 (2), 137-150.

Flagler, C. W. 1940: Report on the Stratigraphy and Foraminifera of the Viborg Core Drill Profile, Mid-Jutland, Denmark, 37 pp. Danish American Prospecting Company, (unpublished report).

Forchhammer, G. 1835: Danmarks geognostiske Forhold, forsaavidt som de ere afhangige af Dannelser, der ere sluttede. $112 \mathrm{pp}$. Copenhagen.

Friis, H. \& Nielsen, O. B. 1980: The Harre Boring. Lithological descriptions. 10 pp. Geol. Inst., Aarhus Univ. (unpublished report).

Friis, H., Nielsen, O. B. \& Heilmann-Clausen, C. 1981: Guide to excursion 14th May 1981. International Geological Correlation Programme, Project 124. The N.W. European Tertiary Basin. 71 pp. Geol. Inst., Aarhus Univ. (unpublished).

Gagel, C. 1906: Über das Alter und die Lagerungsverhältnisse des Schwarzenbecker Tertiärs. Jb. preuss. geol. Landesanst. 27, 399-417.

Gagel, C. 1917: Ein neuer Fossilfund im dänischen Untereozän. Jb. preuss. geol. Landesanst. 37 (2), 60-63.

Gersner, F. 1980: En lithostratigrafisk, kemisk og mineralogisk undersøgelse af Røsnasleret og en del af Lillebaltleret $i$ Danmark. 139 pp. Geol. Inst., Aarhus Univ. (unpublished thesis).

Graff-Petersen, P. 1955: Lillebæltsler. En lermineralogisk undersøgelse. Meddr dansk geol. Foren. 13 (1), 1-14.

Gripp, K. 1964: Erdgeschichte von Schleswig-Holstein. 411 pp. Karl Wachholtz, Neumünster, FDR.

Gruas-Cavagnetto, C. 1967: Complexes sporo-polliniques du Sparnacien du Bassin de Paris. Rev. Palaeobotan. Palynol. 5, 243-261.

Gry, H. 1935: Petrology of the Paleocene Sedimentary Rocks of Denmark. Danm. geol. Unders. (2) 61, 171 pp.

Gry, H. 1941: De istektoniske Forhold i Moleromraadet. Meddr dansk geol. Foren. 9 (5), 586-627.

Gry, H. 1965: Furs Geologi. Dansk Natur - Dansk Skole. Ärsskrift 1964, 45-55.

Gry, H. 1979: Beskrivelse til Geologisk Kort over Danmark. Kortbladet Løgstør. Danm. geol. Unders. (1) 26, 58 pp.

Grönwall, K. A. 1903: Løse Blokke fra Nordtyskland af Stenarter der indeholder vulkansk Aske. Meddr dansk geol. Foren. 2 (9), 13-20.

Hansen, J. M. 1979: Age of the Mo-Clay Formation. Bull. geol. Soc. Denmark 27 (3-4), 89-91.

Hardenbol, J. \& Berggren, W. A. 1978: A New Paleogene Numerical Time Scale. A.A.P.G. Studies in geology 6, 213234.

Harder, P. 1922: Om Grænsen mellem Saltholmskalk og Lellinge Grønsand og nogle bemærkninger om Inddelingen af Danmarks ældre Tertiær. Danm. geol. Unders. (2) 38, 108 pp.

Harrison, R. K., Knox, R. W. O'B. \& Morton, A. C. 1979: Petrography and mineralogy of volcanogenic sediments from DSDP Leg 48, southwest Rockall Plateau, Sites 403 and 404. In: Montadert, L. \& Roberts, D. G. (eds.) Init. Rep. DSDP Vol. XLVIII. U.S. Government Printing Office, Washington, 771-785.

Hartz, N. 1909: Bidrag til Danmarks tertiære og diluviale Flora. Danm. geol. Unders. (2) 20, 292 pp.

Heie, O. E. 1970: Lower Eocene aphids (Insecta) from Denmark. Bull. geol. Soc. Denmark 20 (2), 162-168.

Heilmann-Clausen, C. 1978: Undersøgelse af den fossile dinoflagellatflora $i$ »Plastisk Ler" fra det nordlige Lillebaltområde. 99 pp. Paleoecol. Dept., Aarhus Univ. (unpublished thesis).
Heilmann-Clausen, C. 1980: Paleocene plastic clay from the Vejle Fjord area. Bull. geol. Soc. Denmark 29, 47-52.

Heilmann-Clausen, C. 1982: The Paleocene-Eocene boundary in Denmark. Newsl. Stratigr. 11 (2), 55-63.

Heilmann-Clausen, C. 1983: Dinoflagellate zonation and lithostratigraphy of Palaeocene and Eocene sediments from Denmark. Paleoecol. Dept., Aarhus Univ. (ph.D. thesis).

Henriksen, K. L. 1922: Eocene Insects from Denmark. Danm. geol. Unders. (2) 37, 36 pp.

Henriksen, K. L. 1929: A new Eocene Grashopper, Tettigonia (Locusta) amoena n. sp. from Denmark. Meddr dansk geol. Foren. 7, 317-320.

Hinsch, W. 1974: Das Tertiär im Untergrund von SchleswigHolstein (Das Nordwestdeutsche Tertiärbecken, Beitrag Nr. 5). Geol. Jb. A 24, 34 pp.

Hoch, E. 1975: Amniote remnants from the eastern part of the Lower Eocene North Sea Basin. Colloque international C.N.R.S. 218, 543-562.

Håkansson, E. \& Sjørring, S. 1982: Et molerprofil i kystklinten ved Salger Høj, Mors. Dansk geol. Foren. Arsskr. 1981, 131-134.

Illies, H. 1949: Die Lithogenese des Untereozäns in Nordwestdeutschland. Mitt. geol. StInst. Hamb. 18, 6-44.

Jacqué, M. \& Thouvenin, J. 1975: Lower Tertiary tuffs and volcanic activity in the North Sea. In: Woodland, A. W. (ed.) Petroleum and the continental shelf of North-West Europe, vol. 1. Applied Sci. Publ. Ltd., London, 455-465.

Knox, R. W. O'B. \& Harland, R. 1979: Stratigraphical relationships of the early Palaeogene ash-series of NW Europe. J. geol. Soc. Lond. 136 (4), 463-470.

Knox, R. W. O'B. \& Morton, A. C. 1983: Stratigraphical distribution of Early Palaeogene pyroclastic deposits in the North Sea Basin. Proc. Yorks. Geol. Soc. 44 (3), 355-363.

Knox, R. W. O'B., Morton, A. C. \& Harland, R. 1981: Stratigraphical Relationships of Palaeocene Sands in the UK Sector of the Central North Sea. In: Illing, L. V. \& Hobson, G. D. (eds.): Petroleum Geology of the Continental Shelf of North-West Europe. Institute of Petroleum, London, 267-281

Koch, E. 1960: Moleret. Meddr dansk geol. Foren. 14, 283-284.

Kristoffersen, F. N. \& Bang, I. 1982: Cenozoic excl. Danian limestone. In: Michelsen, O. (ed.): Geology of the Danish Central Graben. Danm. geol. Unders. Ser. B, 8, 62-71.

Larsen, G. \& Dinesen, A. 1959: Vejle Fjord Formationen ved Brejning. Sedimenterne og foraminiferfaunaen (Oligocæn-Miocæn). Danm. geol. Unders. (2) 82, 114 pp.

Larsson, S. G. 1975: Palaeobiology and mode of burial of the insects of the Lower Eocene Mo-clay of Denmark, Bull. geol. Soc. Denmark 24, 193-209.

Larsson, S. G. 1978: Baltic Amber-A Palaeobiological Study. 192 pp. Scandinavian Science Press Ltd., Klampenborg, Denmark.

Madirazza, I. \& Fregerslev, S. 1969: Lower Eocene tuffs at Mønsted, North Jutland. Bull. geol. Soc. Denmark 19 (3), 283-318.

Madsen, V., Ødum, H. \& Gry, H. 1935: Boringerne ved Langbrogaard ved Sønderborg. Danm. geol. Unders. (2) 55, 47 pp.

Malm, O. A., Christensen, O. B., Furnes, H., Løvlie, R., Rueslåtten, H. \& Østby, K. L. 1983: The Lower Tertiary tuff-marker (Balder Fm.) in the Viking Graben: composition, age, source and deposition. Proceedings of the North European margin symposium (NEMS '83), Trondheim 9 11 May 1983. 49 pp. Statoil.

Martini, E. 1971: Standard Tertiary and Quaternary calcareous nannoplankton zonation. In: Farinacci, A. (ed.): Proc. 2nd Planktonic Conf. Roma 1970. Vol. 2. Technoscienza, Roma, 739-785.

Martini, E. 1977: Neue Daten zum Paläozän und Unter-Eozän 
im südlichen Nordseebecken. Newsl. Stratigr. 6 (2), 97105.

Martini, E. \& Müller, C. 1971: Das marine Alttertiär in Deutschland und seine Einordnung in die Standard Nannoplankton Zonen. Erdöl und Kohle 24, 381-384.

Mertz, E. L. 1928: Lillebeltsler og London Clay. Danm. geol. Unders. (2) 51, $66 \mathrm{pp}$.

Mertz, E. L. 1937: Geologiske Profiler gennem danske Sunde og Fjorde; med nogle Bemarkninger om dertil knyttede geotekniske Forhold. Danm. geol. Unders. (2) 60, 144 pp.

Mikkelsen, N. 1975: Marine Lower Oligocene sediments in Denmark as indicated by coccoliths in the Viborg Formation. Bull. geol. Soc. Denmark 24, 83-86.

Milthers, V. 1943: Nordvestsjællands Geologi. Danm. geol. Unders. (5) 6, 185 pp.

Morton, A. C., Backman, J. \& Harland, R. 1983: A reassessment of the stratigraphy of DSDP Hole 117A, Rockall Plateau: implications for the Palaeocene-Eocene boundary in N.W. Europe. Newsl. Stratigr. 12 (2), 104-111.

Nielsen, E. 1959: Eocene Turtles from Denmark. Meddr dansk geol. Foren. 14, 96-114.

Nielsen, E. 1960: A new Eocene teleost from Denmark. Meddr dansk geol. Foren. 14, 247-252.

Nielsen, E. 1963: On the postcranial skeleton of Eosphargis breineri Nielsen. Meddr dansk geol. Foren. 15, 281-313.

Nielsen, O. B. 1973: Eocæne aflejringer i Ølst-området og deres indpasning i omrădets Kvartærgeologi. Dansk geol. Foren. Arsskr. 1972, 100-110.

Nielsen, O. B. 1974: Sedimentation and diagenesis of Lower Eocene sediments at ÖIst, Denmark. Sediment. Geol. 12, 25-44.

Norin, R. 1940: Problems concerning the volcanic ash layers of the lower Tertiary of Denmark. Geol. Fören. Stockh. Förh. $62(1), 31-44$.

Pannekoek, A. J. 1956: Geological History of the Netherlands. 147 pp. 's-Gravenhage Staatsdrukkerij en Uitgeverijbedrijf, the Hague.

Pedersen, A. K., Engell, J. \& Rønsbo, J. G. 1975: Early Tertiary volcanism in the Skagerrak: New chemical evidence from ash-layers in the Mo-clay of northern Denmark. Lithos 8, 255-268.

Pedersen, G. K. 1981: Anoxic events during sedimentation of a Palaeogene diatomite in Denmark. Sedimentology 28 (4), 487-504.

Pedersen, G. K. \& Surlyk, F. 1977: Dish structures in Eocene volcanic ash layers, Derimark. Sedimentology 24 (4), 581590.

Pedersen, G. K. \& Surlyk, F. 1983: The Fur Formation, a late Paleocene ash-bearing diatomite from northern Denmark. Bull. geol. Soc. Denmark 32, 43-65.

Pedersen, K. R. 1960: Moleret. Meddr dansk geol. Foren. 14, 284.

Perch-Nielsen, K. 1967: Nannofossilien aus dem Eozän von Dänemark. Eclog. geol. Helv. 60 (1), 19-32.

Perch-Nielsen, K. 1968: Beobachtungen im Elektronenmikroskop an Micrantholithus mirabilis und Marthasterites obscurus (Nannoplankton). Meddr dansk geol. Foren. 18 (2), 251-254.

Perch-Nielsen, K. 1971: Elektronenmikroskopische Untersuchungen an Coccolithen und verwandten Formen aus dem Eozăn von Dänemark. Biol. Skr. Dan. Vid. Selsk. 18 (3), $76 \mathrm{pp}$.

Perch-Nielsen, K. 1976: New silicoflagellates and a silicoflagellate zonation in north European Palaeocene and Eocene diatomites. Bull geol. Soc. Denmark 25 (1-2), 27-40.

Petersen, K. S. 1969: Fossiler og hærdnede spor af liv i eocænt ler fra Røsnæs. Meddr dansk geol. Foren. 19 (1), 139-141.

Petersen, K. S. 1973: Some features in Clay with Tuff-beds from Lower Eocene on Røsnæs, Denmark. Danm. geol. Unders. Árbog 1972, 69-78.
Petersen, K. S., Hoch, E. \& Bonde, N. 1973: A new species of Mytilid bivalve, and vertebrate remains from Lower Eocene marine deposits on Røsnæs, Denmark. Danm. geol. Unders. Arbog 1972, 79-86.

Prinz, W. 1880: Études sur des coupes de diatoméees observées dans les lames minces de la roche de Nykjobing (Jutland) Annls Soc. belge Microsc. 7, Memoires, $16 \mathrm{pp}$.

Prinz, W. 1885: A propos des coupes de diatomées du "Cementstein" du Jutland. Description minéralogique de cette roche. Bull. Soc. belge Microsc. 11, 147-193.

Prinz, W. \& van Ermengem, E. 1883: Recherches sur la structure de quelques diatomés contenues dans le "Cementstein" du Jutland. Annls Soc. belge Microsc. 8, 7-65.

Rasmussen, H. W. 1972: Lower Tertiary Crinoidea, Asteroidea and Ophiuroidea from Northern Europe and Greenland. Biol. Skr. Dan. Vid. Selsk. 19 (7), 83 pp.

Rasmussen, H. W. 1977: Geologi på Mols. Danm. geol. Unders. Ser. $A, 4,22$ pp.

Rasmussen, L. B. 1967: Tertiarperioden. In: Danmarks Natur 1. Politikens Forlag, Copenhagen, 161-198.

Ravn, J. P. J. 1897: Nogle Bemarkninger om danske Tertiaraflejringers Alder. Meddr dansk geol. Foren. 1 (4), 1-16.

Ravn, J. P. J. 1906: Om det saakaldte plastiske Lers Alder. Meddr dansk geol. Foren. 2 (12), 23-28.

Ravn, J. P. J. 1915: Om Fossile Terebellide-Rør fra Danmark. Meddr dansk geol. Foren. 4 (4), 383-390.

Ravn, J. P. J. 1928: The Tertiary. In: Nordmann, V. (ed.) Summary of the Geology of Denmark. Danm. geol. Unders. (5) 4, 64-77.

Rosenkrantz, A. 1945: Småbidrag til Danmarks Geologi 1-8. 7. Moleret i Silstrup Sydklint. Meddr dansk geol. Foren. 10 (4), 455-458.

Rosenkrantz, A. 1968: En nautil fra det plastiske ler samt en oversigt over slægten Cimomia's optræden i danske aflejringer. Meddr dansk geol. Foren. 18, 152-153.

Seibertz, E. \& Vortisch, W. 1979: Zur Stratigraphie, Petrologie und Genese einer Bentonit-Lage aus dem oberen MittelTuron (Oberkreide) des südöstlichen Münsterlandes. Geol. Rdsch. 68 (2), 649-679.

Sharma, P. V. 1969: Early Tertiary field reversals recorded in volcanic ash layers of northern Denmark. Bull. geol. Soc. Denmark 19 (2), 218-223.

Sorgenfrei, T. 1957: Formations of Denmark. In: Lexique Strat. Int. Vol. 1 (2d).Paris, 1-44.

Sorgenfrei, T. \& Berthelsen, O. 1954: Geologi og Vandboring. Danm. geol. Unders. (3) 31, $106 \mathrm{pp}$.

Sorgenfrei, T. \& Buch, A. 1964: Deep tests in Denmark 19351959. Danm. geol. Unders. (3) $36,146 \mathrm{pp}$.

Spjeldnæs, N. 1975: Palaeogeography and facies distribution in the Tertiary of Denmark and surrounding areas. Norges geol. Unders. 316, 289-311.

Stolley, E. 1899: Ueber Diluvialgeschiebe des Londonthons in Schleswig-Holstein und das Alter der Molerformation Jütlands, sowie das baltische Eocän überhaupt. Arch. $A n$ throp. Geol. Schlesw.-Holst. 3 (2), 105-146.

Surlyk, F. 1980: Denmark. In: Geology of the european countries vol. 2. Dunod, 1-50.

Tank, R. W. 1963: Clay mineralogy of some lower Tertiary (Paleogene) sediments from Denmark. Danm. geol. Unders. (4) 4, (9), 45 pp.

Thiede, J., Nielsen, O. B., \& Perch-Nielsen, K. 1980: Lithofacies, Mineralogy and Biostratigraphy of Eocene Sediments in Northern Denmark (Deep Test Viborg 1). N. Jb. Geol. Paläont. Abh. 160 (2), 149-172.

Unmack, A. 1944: Resultater af nyere Lerunders $\varnothing$ gelser. Den Røntgenografiske Metodes anvendelse paa 2 danske Lerarter. Roy. Veter. Agric. Coll. Copenh. Yearbook 1944, 33-59.

Unmack, A. 1949: X-ray investigation of some Danish clays. II. 
Montmorillonitic clays. Roy. Veter. Agric. Coll. Copenh. Yearbook 1949, 192-204.

Ussing, N. V. 1904: Danmarks Geologi i almenfatteligt Omrids. Danm. geol. Unders. (3) 2 (second edition), $358 \mathrm{pp}$.

Ussing, N. V. 1907: Om Floddale og Randmoræner i Jylland. Overs. K. danske Vidensk. Selsk. Forh. 1907 (4), 161-213.

Ussing, N. V. 1910: Dänemark. In: Handbuch der regionalen Geologie Vol. 1 (2). Carl Winter, Heidelberg 1-38.

Ussing, N. V. 1913: Danmarks Geologi i almenfatteligt omrids. Danm. geol. Unders. (3) 2 (third edition), 372 pp.
Waagstein, R. \& Johhansen, J. 1968: Tre vulkanske askelag fra Færøerne. Meddr dansk geol. Foren. 18, 257-264.

Wirtz, D. 1939: Das Alttertiär in Schleswig-Holstein. Neues Jb. Min. BeilBd 81, 215-297.

Ziegler, P. A. 1981: Evolution of Sedimentary Basins in NorthWest Europe. In: Illing, L. V. \& Hobson, G. D. (eds.): Pe troleum Geology of the Continental Shelf of North-West Europe. Institute of Petroleum, London, 3-39.

Ødum, H. 1936: Marint Nedre Oligocan i Danmark. Meddr dansk geol. Foren. 9 (1), 88-90. 